Published in "Marine Geology 282(1-2): 26-39, 2011"

which should be cited to refer to this work.

\title{
Growth and demise of cold-water coral ecosystems on mud volcanoes in the West Alboran Sea: The messages from the planktonic and benthic foraminifera
}

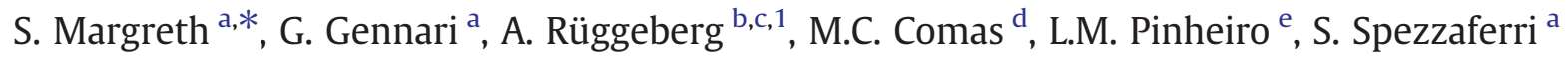 \\ a University of Fribourg, Department of Geosciences, Earth Sciences, Ch. du Musée 6, 1700 Fribourg, Switzerland \\ b Leibniz-Institut für Meereswissenschaften (IFM-GEOMAR), Wischhofstasse 1-3, D-24148 Kiel, Germany \\ ' Renard Centre of Marine Geology, Ghent University, Krijgslaan 281, S8, B-9000 Gent, Belgium \\ ${ }^{\mathrm{d}}$ Instituto Andaluz de Ciencias de la Terra (C.S.I.C. University of Granada), Campus Fuentenueva sln, 18002 Granada, Spain \\ e Universidade de Aveiro, Departamento de Geociências and CESAM, 3810-193 Aveiro, Portugal
}

\begin{abstract}
The Dhaka and Maya mud volcanoes (MVs), located in the Mud Diapir Province in the Western Alboran Basin along the Moroccan Coasts, were cored during the TTR-17, Leg 1 cruise. Cores were taken on the top of the volcanoes at a water depth of $370 \mathrm{~m}$ on the Dhaka MV (core TTR17-MS411G) and at $410 \mathrm{~m}$ water depth on the Maya MV (core TTR17-MS419G), respectively. On both mud volcanoes the extruded mud breccia provides the nucleation point for the colonization and development of cold-water corals and associated ecosystems. Two phases of cold-water coral growth are observed: (1) between slightly older than $4175 \pm 62$ years BP and around $2230 \pm 59$ years BP at Dhaka, and (2) between slightly older than $15583 \pm 185$ years BP and around $7613 \pm$ 38 years BP at Maya MV. On the top of the Maya MV only a small patch reef and/or isolated corals proliferated, whereas a more extended patch reef colonized the top of the Dhaka MV. At both sites the cold-water coral development was triggered by the availability of a suitable substrate for initial coral settling, provided either as a firm ground or as single clasts. Subsequently coral growth was supported by enhanced nutrient flux possibly related to upwelling and/or strong currents. During the intervals of coral growth planktonic foraminiferal assemblages were dominated by Neogloboquadrina incompta. The decline of coral ecosystems on the mud volcanoes is accompanied at surface by a shift from the N. incompta dominated assemblage to a Globorotalia inflata dominated assemblage, possibly reflecting more oligotrophic conditions. This shift is coeval to the passage from wet to arid conditions at the end of the African Humid Period at Maya MV. It is interpreted as an effect of an early human impact on a fragile environment, which was already stressed by desiccation at the time of the development of complex human society along the Mediterranean coasts, at Dhaka MV.
\end{abstract}

\section{Introduction}

Mud volcanoes and mud diapirs are common features in the Alboran Sea in the Western Mediterranean (e.g., Sautkin et al., 2003) and along the Atlantic margin of the associated Gulf of Cadiz (e.g., Pinheiro et al., 2003; Somoza et al., 2003; Fernandez-Puga et al., 2007). Mud volcanism and associated phenomena such as cold seepage, hydrocarbon venting and gas hydrates in the Gulf of Cadiz have been investigated since 1996 (Baraza and Ercilla, 1996; Baraza et al., 1999; Ivanov et al., 2000, 2001; Somoza et al., 2000; Gardner, 2001; Kenyon et al., 2001; Mazurenko et al., 2002; Pinheiro et al., 2003). An exploratory cruise of $R / V$ Belgica in

\footnotetext{
* Corresponding author. Tel.: +4126300 88 79; fax: +41263009742. E-mail addresses: stephan.margreth@unifr.ch (S. Margreth), giordana.gennari@unifr.ch (G. Gennari), andres.ruggeberg@ugent.be, andres.ruggeberg@ees.kuleuven.be (A. Rüggeberg), mcomas@ugr.es (M.C.Comas) lmp@ua.pt (L.M. Pinheiro), silvia.spezzaferri@unifr.ch (S. Spezzaferri).

1 Present address: Department of Earth and Environmental Sciences, K.U. Leuven, Celestijnenlaan 200E, B-3001 Heverlee, Belgium.
}

2002 on an accretionary setting in the Gulf of Cadiz (Gutscher et al., 2002) off Larache (Morocco), led to the discovery of a cluster of nine mud volcanoes: the El Arraiche mud volcanoes field (Van Rensbergen et al., 2005). These structures occur in close association to cold-water coral carbonate mounds, which are up to $60 \mathrm{~m}$ high and located in water depths of 500-600 m on the Pen Duik Escarpement (Van Rensbergen et al., 2005; Foubert et al., 2008; Wienberg et al., 2009).

The existence of mud volcanoes in the Alboran Sea was first documented in 1999 during the UNESCO-IOC Training Through Research Program (TTR-9) Leg 2 along the Moroccan margin. A further survey carried out in 2002 with the $R / V$ Logachev during TTR-12 Leg 3 revealed the existence of mud volcanism along both Spanish (Northern Mud-Volcano Field) and Moroccan (Southern Mud-Volcano Field) margins of the West Alboran Basin. Additional mud volcanoes were discovered during the TTR-14 campaign between the northern and southern mud-volcano fields (Comas et al., 2000, 2003a,b; Sautkin et al., 2003; Talukder et al., 2003; Comas and Ivanov, 2006). In 2007, a cruise of the $R / V$ Hesperides focusing on mud volcanoes in the Alboran Sea (Comas and Pinheiro, 2007) unveiled an outcropping mound province off 
Melilla, which displays striking affinities with the Cadiz cold-water coral carbonate mounds and with those discovered in the North Atlantic (e.g., Henriet et al., 1998). The Melilla field was cored for the first time in June 2008 during the TTR-17 cruise (Comas and the SAGAS08-TTR17, Leg 1Scientific Party, unpublished). During the same cruise mud volcanoes from the southern part of the Alboran Sea were also cored. A few cores contained intervals characterized by cold-water coral fragments. Coldwater corals have been identified in the Mediterranean Sea since the 60s (see McCulloch et al., 2010 and reference therein). However, only recently their full extent and distribution has been mapped. McCulloch et al. (2010) have compiled a data set summarizing the occurrence of cold-water coral from the Eastern to the Western Mediterranean according to their age and paleoenvironment. In this study, the westernmost analyzed cores were in the Eastern Alboran Sea. Therefore, a few data are presently available for the Western Alboran.

This study aims to investigate the sedimentary sequence deposited on the top of Dhaka and Maya MVs in the Alboran Sea (Fig. 1), to reconstruct the paleoceanographic setting and to identify a possible causal link between cold-water coral growth and the mud volcanoes activity.

\section{Regional setting}

The Alboran Sea is a $400 \mathrm{~km}$ long and $200 \mathrm{~km}$ wide basin with a water depth not exceeding $2 \mathrm{~km}$, located in the westernmost part of the Mediterranean Sea (e.g., Comas et al., 1999). Its complex seafloor morphology shows ridges, seamounts and troughs and it is divided in three sub-basins: the West Alboran, the East Alboran and the South Alboran Basins (Fig. 1). The West Alboran and the South Alboran Basins are separated by the Alboran Ridge, a prominent NE-SW linear relief, locally forming the small Alboran Island.

The formation of the Alboran Basin as part of the Gibraltar Arc started in the late Cretaceous as a consequence of crustal extension in a setting of overall convergence of the African and Eurasian plates that have had variable directions of relative motion since the late Cretaceous (e.g., Dewey et al., 1989). Seismic data show that present-day plate tectonics contribute to the actual deformation of the Alboran Basin (e.g.,
Fernández-Ibáñez et al., 2007 and references therein; Frizon de Lamotte et al., 2006). Early Miocene under-compacted shales and olistostromic sediments mobilized by fluid flows in a back-arc basin setting characterized by coeval extensional tectonics have been suggested as the source layer for the Mud Diapir Province in the Western Alboran Basin, which during the post-Messinian compressive tectonics developed piercing diapirs and subsequent mud volcanoes (Comas et al., 1992, 1999; Comas et al., 1992; Chalouan et al., 1997; Pérez-Belzuz et al., 1997; Sautkin et al., 2003; Talukder et al., 2003).

The Alboran Sea represents the transitional zone between Atlantic (AW, cold, low saline and nutrient-rich) and the Mediterranean (MW, warmer and with higher salinity) type water. Air-sea interaction processes modify the AW while it flows at the surface from west to east and give origin to the Modified Atlantic Water - MAW (Millot, 2009). Levantine Intermediate Water (LIW) generated in the Eastern Mediterranean Sea, flows in the opposite direction below the MAW. Western Mediterranean Deep Water (WMDW), fills the deepest part of the basin (e.g., Jimenez-Espejo et al., 2008 and references therein).

The hydrography is also controlled by local winds, which are a direct consequence of atmospheric pressure gradients between the Western Mediterranean and the Gulf of Cadiz (e.g., García Lafuente et al., 2002). Changes in the water flow through the Strait of Gibraltar are modulated by this wind forcing as suggested by García Lafuente et al. (2002). Wind forcing also regulates the formation of gyres within the Alboran Sea and the transportation of atmospheric dust and moisture (e.g., Bucca and Kinder, 1984; Rodriguez et al., 2001; Jimenez-Espejo, et al., 2008).

The recent Mediterranean Sea is overall oligotrophic (Cruzado, 1985). However, one of its highest productivity areas is in the Alboran Sea where it is associated to upwelling triggered by the hydrological structure of surface waters (Morel, 1991). The Atlantic inflow and the eolian and fluvial influxes are also responsible for nutrient transport into the Alboran Sea (Dafner et al., 2001).

\subsection{Dhaka and Maya mud volcanoes}

The Dhaka and Maya MVs are located in the Mud Diapir Province in the Western Alboran Basin (35 $25.43^{\prime} \mathrm{N} ; 04^{\circ} 31.89^{\prime} \mathrm{W}$ and $35^{\circ} 27.11^{\prime} \mathrm{N}$;

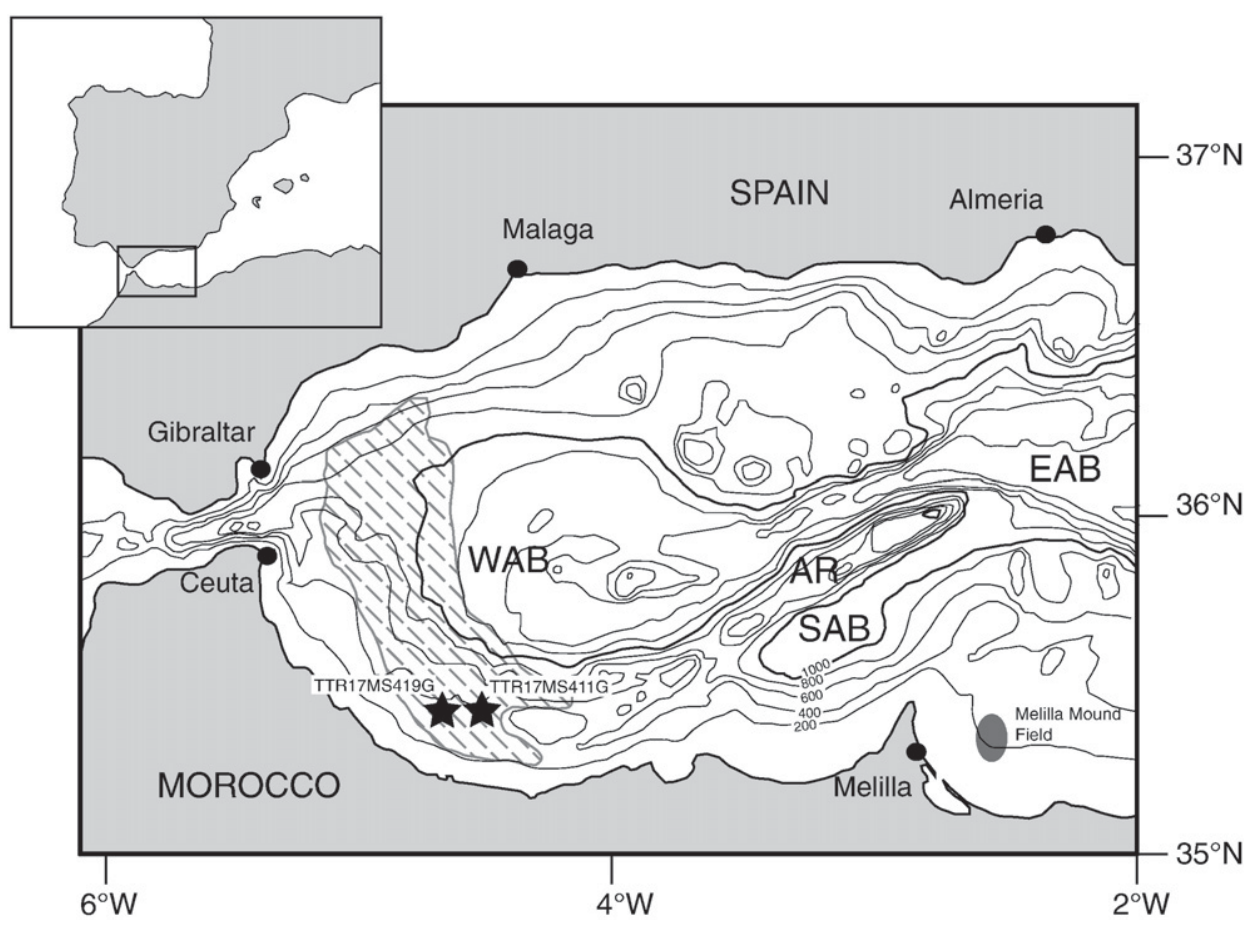

Fig. 1. Location map of the studied cores. Shaded area: Mud Diapir Province. WAB: West Alboran Basin; EAB: East Alboran Basin; SAB: South Alboran Basin; AR: Alboran Ridge. Modified from Comas et al. (1999) and Comas and the SAGAS08-TTR17, Leg 1-Scientific Party (unpublished). 
$04^{\circ} 37.14^{\prime}$ W respectively) offshore the Moroccan coast. The Dhaka mud volcano is a semi-circular structure with a diameter of about $1 \mathrm{~km}$. The Maya MV is elongated in an E-W direction and about $120 \mathrm{~m}$ long. Cores were taken on the top of the volcanoes at a water depth of $370 \mathrm{~m}$ on the Dhaka MV (TTR17-MS411G) and at $410 \mathrm{~m}$ water depth on the Maya MV (TTR17-MS419G) (Fig. 1; Table 1).

The sedimentary succession cored at the Dhaka MV includes from top to bottom a hemi-pelagic drape $(0-30 \mathrm{~cm})$, a cold-water coral fragments-rich unit (30-60 cm), a mud-breccia layer $(60-145 \mathrm{~cm})$, and possibly a lowermost level of pelagic sediments mixed with the mud breccia (from $145 \mathrm{~cm}$ to the base of the core). The mud breccia is represented by a stiff clayey matrix containing clasts, up to $20 \mathrm{~cm}$ in size of marls and lithified and semi-lithified clays.

The succession cored at the Maya MV includes, from top to bottom, a hemi-pelagic drape $(0-95 \mathrm{~cm})$, a cold-water coral fragments-rich unit $(95-125 \mathrm{~cm})$, and a mud-breccia layer $(125 \mathrm{~cm}$ to the base of the core) composed of clasts of marls and lithified clays, up to $3 \mathrm{~cm}$ in size, embedded in a stiff clayey matrix. Both volcanoes are presently not active as testified by the presence of a pelagic drape on their top.

\section{Material and methods}

The hemi-pelagic drape has been sampled at $5 \mathrm{~cm}$ resolution (Dhaka) and 2 to $10 \mathrm{~cm}$ resolution (Maya) for planktonic and benthic foraminiferal investigations. Samples for micropaleontological analyses were processed following standard procedures (e.g., Spezzaferri and Coric, 2001), dried at room temperature, weighted and washed through $250 \mu \mathrm{m}, 125 \mu \mathrm{m}$ and $63 \mu \mathrm{m}$ mesh sieves. Residues of the obtained three size fractions were dried at room temperature and weighted. About 200 specimens per fraction (600 specimens per sample) were picked, and classified at species level. Residues containing more than 300 specimens were split. Samples containing less than 100 specimens per fraction were fully analyzed. Benthic and planktonic foraminiferal species are listed in Appendix A.

A multivariate statistical treatment on faunal data was performed with the software PRIMER 6 (Clarke, 1993; Clarke and Warwick, 2001; Clarke and Gorley, 2006). Data have been double-square root transformed to limit the contribution of the most abundant and ubiquitous species (Field et al., 1982). Bray-Curtis (dis-) similarities were calculated following Clifford and Stephenson (1975). The same similarity matrix was used to obtain the non-metric MultiDimensional Scaling (nMDS plot) (Kruskal, 1964; Kruskal and Wish, 1978). The significance and potential of the nMDS plot has been discussed in detail in Spezzaferri and Coric (2001) and Margreth et al. (2009). Based on the clusters given in the nMDS plot, the Similarity Percentage Analysis (SIMPER) was obtained to highlight the contribution of each species to the total average (dis-) similarity between different groups and within one group (e.g., Kruskal, 1964; Kruskal and Wish, 1978; Basso and Spezzaferri, 2000; Clarke and Warwick, 2001). Quantitative data of benthic and planktonic foraminifera used for the multivariate statistic are given in Appendix B.

The chronology of the two cores retrieved from Dhaka and Maya MVs (TTR17-MS411G and TTR17-MS419G, respectively) is based on 8 AMS ${ }^{14} \mathrm{C}$ ages (Table 2) obtained at the Leibniz Laboratory for Age Determinations and Isotope Research at the University of Kiel. For each sample, at least $5 \mathrm{mg}$ of Globorotalia inflata were handpicked to provide

Table 1

Geographic position and water depths of the two investigated cores.

\begin{tabular}{lllll}
\hline Gravity core & Site & $\begin{array}{l}\text { Length } \\
(\mathrm{cm})\end{array}$ & Position & $\begin{array}{l}\text { Water depth } \\
(\mathrm{m})\end{array}$ \\
\hline TTR17-MS411G & $\begin{array}{l}\text { Dhaka mud } \\
\text { volcano }\end{array}$ & 162 & $35^{\circ} 25.43^{\prime} \mathrm{N} ; 04^{\circ} 31.89^{\prime} \mathrm{W}$ & 370 \\
TTR17-MS419G & $\begin{array}{l}\text { Maya mud } \\
\text { volcano }\end{array}$ & 167 & $35^{\circ} 27.11^{\prime} \mathrm{N} ; 04^{\circ} 37.14^{\prime} \mathrm{W}$ & 410 \\
\hline
\end{tabular}

0.2 to $1.2 \mathrm{mg}$ of carbonate. The organic material was removed in an ultrasonic bath with $15 \% \mathrm{H}_{2} \mathrm{O}_{2}$. The hydrolysis of the residual pure calcite was obtained at $90{ }^{\circ} \mathrm{C}$ with $100 \%$ orthophosphoric acid. The carbon dioxide was converted to graphite with hydrogen on an iron catalyst. The iron-graphite mixture was measured on the AMS mass spectrometer. A reservoir correction of 400 years (Siani et al., 2000) was subtracted to the obtained radiocarbon conventional ages, which were calibrated using the program Calib 5.1 (Stuiver and Reimer, 1993).

Stable oxygen and carbon isotope analyses $\left(\delta^{18} \mathrm{O}\right.$ and $\left.\delta^{13} \mathrm{C}\right)$ on about 5-10 specimens of Discanomalina coronata were performed on 3 samples from the coral-rich level of the Dhaka MV (Table 3). These isotope ratios were measured on a Finnigan MAT 252 mass spectrometer with a Kiel II preparation device at the IFM-GEOMAR, LeibnizInstitute of Marine Sciences (Kiel University). The reproducibility was \pm $0.035 \%$ ofor $\delta^{18} \mathrm{O}$ and $\pm 0.029 \%$ of $\delta^{13} \mathrm{C}$. The isotope ratios are presented relative to Vienna Pee Dee Belemnite standard (VPDB) based on calibrations of National Bureau of Standards (NBS).

\section{Results}

\subsection{Micropaleontology}

A hemi-pelagic unit and a cold-water coral fragments-rich unit on top of the mud breccia characterize both Dhaka and Maya MVs. The hemi-pelagic sediments at Dhaka MV (0-30 cm) and at Maya MV (0$95 \mathrm{~cm}$ ) yield very similar foraminiferal assemblages. Planktonic species include very abundant Globorotalia inflata, Globigerinoides spp., Turborotalita quinqueloba and Globigerinita glutinata while benthic foraminifera are mainly represented by species such as Globocassidulina subglobosa, Uvigerina mediterranea, Cassidulina carinata, and Bolivina difformis (Appendix A).

The cold-water coral fragments-rich unit at both mud volcanoes is dominated by the planktonic species Neogloboquadrina incompta, Turborotalita quinqueloba and associated less abundant Globigerinita glutinata and Globigerina bulloides. In this unit, epifaunal-attached benthic foraminifera are abundant and consist of Discanomalina coronata, Cibicidoides pachyderma, Cibicidoides sp., Angulogerina angulosa, and Lobatula lobatula (Appendix B). The samples also contain fragments of cold-water corals attributed to Madrepora oculata, Lophelia pertusa and to the solitary species Desmophyllum sp. and/or Dendrophyllia sp. (Plate 1).

\subsection{Quantitative and statistical analyses}

Quantitative analyses of planktonic and benthic foraminifera were performed on samples from the hemi-pelagic drape and the coral-rich unit of both mud volcanoes to evaluate species abundance and diversities (Fig. 2).

Planktonic foraminifera (Dhaka MV) - a clear positive peak of abundance (almost 50\%) is observed for $N$. incompta at about $50 \mathrm{~cm}$ (Fig. 2A) within the interval containing coral fragments. Abundance of

Table 2

Result of AMS ${ }^{14} \mathrm{C}$ dating on planktonic foraminifera G. inflata. Calibration using the software Calib 5.1 (Stuiver and Reimer, 1993). A reservoir effect of 400 years was subtracted (Siani et al., 2000).

\begin{tabular}{lrlllc}
\hline Core & $\begin{array}{l}\text { Depth } \\
(\mathrm{cm})\end{array}$ & Species & Lab code & $\begin{array}{l}\text { Conventional } \\
(\mathrm{yr} \mathrm{BP})\end{array}$ & $\begin{array}{l}\text { Calibrated age } \\
(\mathrm{yr} \mathrm{BP})\end{array}$ \\
\hline TTR17-MS411G & 0 & Gr. inflata & KIA 39074 & $1145 \pm 30$ & $689 \pm 27$ \\
TTR17-MS411G & 35 & Gr. inflata & KIA 39075 & $2550 \pm 40$ & $2230 \pm 59$ \\
TTR17-MS411G & 55 & Gr. inflata & KIA 39076 & $4120 \pm 35$ & $4175 \pm 62$ \\
TTR17-MS411G & 150 & Gr. inflata & KIA 39078 & $4240 \pm 40$ & $4345 \pm 60$ \\
TTR17-MS419G & 0 & Gr. inflata & KIA 39197 & $1475 \pm 25$ & $1013 \pm 40$ \\
TTR17-MS419G & 25 & Gr. inflata & KIA 39198 & $2425 \pm 35$ & $2059 \pm 53$ \\
TTR17-MS419G & 98 & Gr. inflata & KIA 39199 & $7145 \pm 40$ & $7613 \pm 38$ \\
TTR17-MS419G & 115 & Gr. inflata & KIA 39200 & $13580 \pm 70$ & $15583 \pm 185$ \\
\hline
\end{tabular}


Table 3

Benthic $\delta^{13} \mathrm{C}$ and $\delta^{18} \mathrm{O}$ measured on Discanomalina coronata from three samples of core TTR17-MS411G (Dhaka MV).

\begin{tabular}{lllcl}
\hline Core & $\begin{array}{l}\text { Depth } \\
(\mathrm{cm})\end{array}$ & Species & $\begin{array}{l}\delta^{13} \mathrm{C} \\
(\% \circ \mathrm{VPDB})\end{array}$ & $\begin{array}{l}\delta^{18} \mathrm{O} \\
(\% \text { VPDB })\end{array}$ \\
\hline TTR17-MS411G & 35 & D. coronata & 0.013 & 2.933 \\
TTR17-MS411G & 55 & D. coronata & -0.218 & 3.542 \\
TTR17-MS411G & 70 & D. coronata & -0.661 & 3.118 \\
\hline
\end{tabular}

G. inflata increases from $45 \mathrm{~cm}$ upwards to over $30 \%$ in the upper part of the core with a negative peak (10\%) at $35 \mathrm{~cm}$. In the hemi-pelagic sediments above the coral-rich interval the abundances of $N$. incompta and Globigerinoides spp. remain below $10 \%$.

Benthic foraminifera (Dhaka MV) - in the interval containing also coral fragments D. coronata is more abundant (around 15\%; Fig. 2B). From the base of this interval to the top of the core, the abundance of G. subglobosa increases from a minimum of around 10 to $25 \%$, respectively. $U$. mediterranea also increase in abundance but never exceeds $10 \%$.

Planktonic foraminifera (Maya MV) - the lower abundances of $G$. inflata and Globigerinoides spp. are observed in the level containing also coral fragments (Fig. 2C), whereas $N$. incompta is very abundant (maximum value 40\%). At about $85 \mathrm{~cm}$, the curves of the three species reverse their trend: G. inflata becomes abundant (almost 30\%) while $N$. incompta and Globigerinoides spp. never exceed 15\%, showing a strict resemblance to the trend of the same species at Dhaka mud volcano.
Benthic foraminifera (Maya MV) - D. coronata is rare but present (1\%) only in the coral-rich level in this core (Fig. 2D). G. subglobosa increases in abundance from the base of the coral-rich horizon (7\%) to the top of the core (22\%). Uvigerinids are not abundant, the highest abundance of $U$. peregrina (around 15\%) is observed at the top of the coral-rich level.

To highlight patterns of community structures that are not clear and/ or readily apparent and to characterize changes in the assemblage structures and relate them to changing environmental conditions, complete foraminiferal data sets were statistically treated. The multivariate statistical analyses including agglomerative clustering based on the Bray-Curtis similarity are shown in Fig. 3. Two clusters separate for planktonic and three clusters for benthic foraminifera as shown in the nMDS plots (Fig. 3). Species and groups accounting for the average similarity and dissimilarity in all clusters are listed in order of decreasing contribution in Tables 4-7.

\section{3. $A M S{ }^{14} \mathrm{C}$ dating and sedimentation rate}

The results of the AMS ${ }^{14} \mathrm{C}$ dating are reported in Table 2. The sediments from Core TTR17-MS411G (Dhaka MV) yield ages ranging from $4346 \pm 60$ years at the bottom (at $150 \mathrm{~cm}$ ) to $689 \pm 27$ years at the core top. Two samples at 55 and $35 \mathrm{~cm}$ containing coral fragments yield ages of $4175 \pm 62$ years BP and $2230 \pm 59$ years BP, respectively (Table 2). In Core TTR17-MS419 G (Maya MV) a sample at $115 \mathrm{~cm}$ containing coral fragments yield an age of $15583 \pm 185$ years BP. The core top is dated as old as $1013 \pm 40$ years BP. A sample at $98 \mathrm{~cm}$

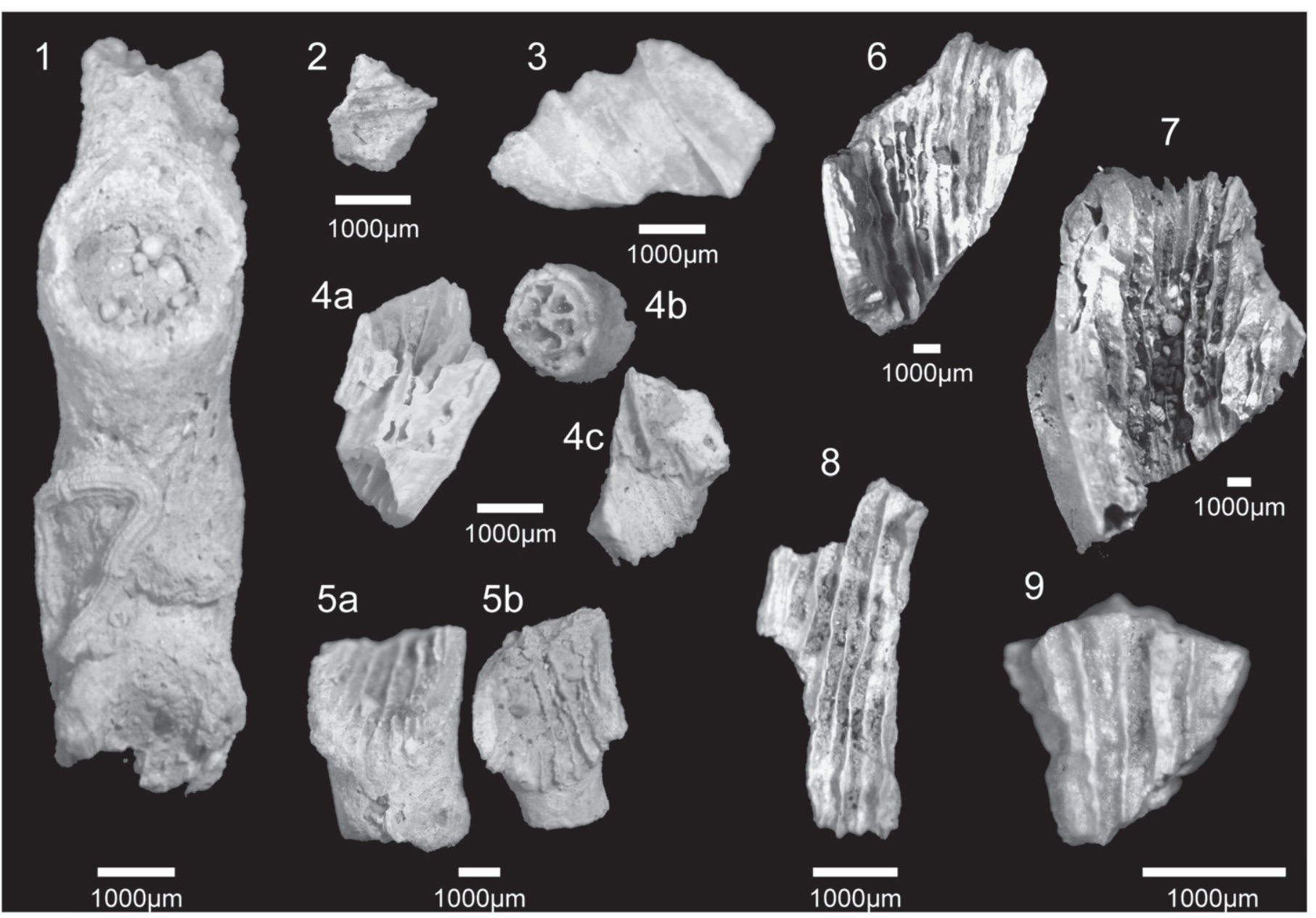

Plate 1. Scleractinian cold-water coral fragments, most certainly Madrepora oculata, Lophelia pertusa and solitary species like Desmophyllum sp. or Dendrophyllia sp. from the two investigated cores: 1. D25; TTR17-MS411G; 25 cm. 2. D45; TTR17-MS411G; 45 cm. 3. D40; TTR17-MS411G; 40 cm. 4a-c. D30; TTR17-MS411G; 30 cm. 5a-b. D25; TTR17-MS411G; 25 cm. 6. M115; TTR17-MS419G; 115 cm. 7. M107; TTR17-MS419G; 107 cm. 8. M100; TTR17-MS419G; 100 cm. 9. M102; TTR17-MS419G; 102 cm. 


\section{Dhaka MV \\ TTR17-MS411G}

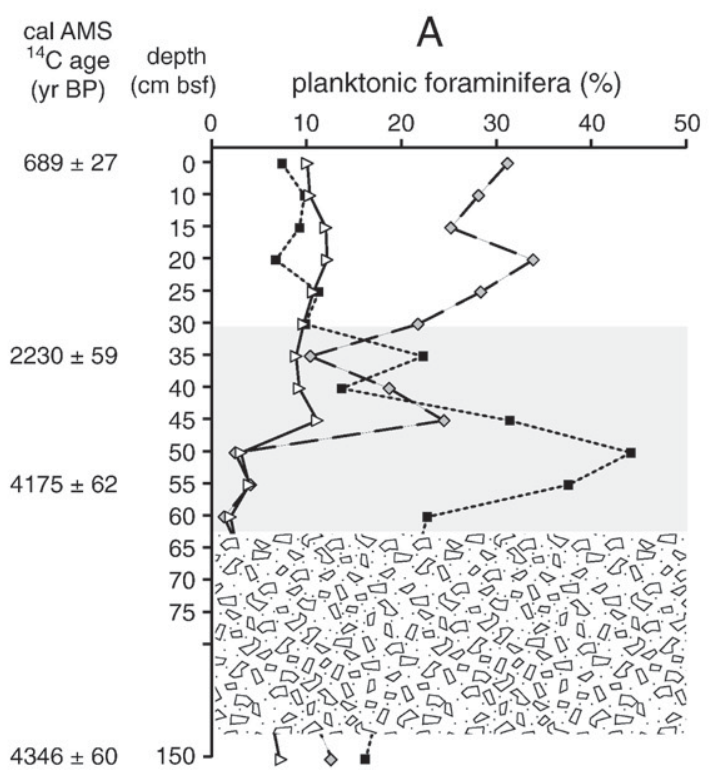

B

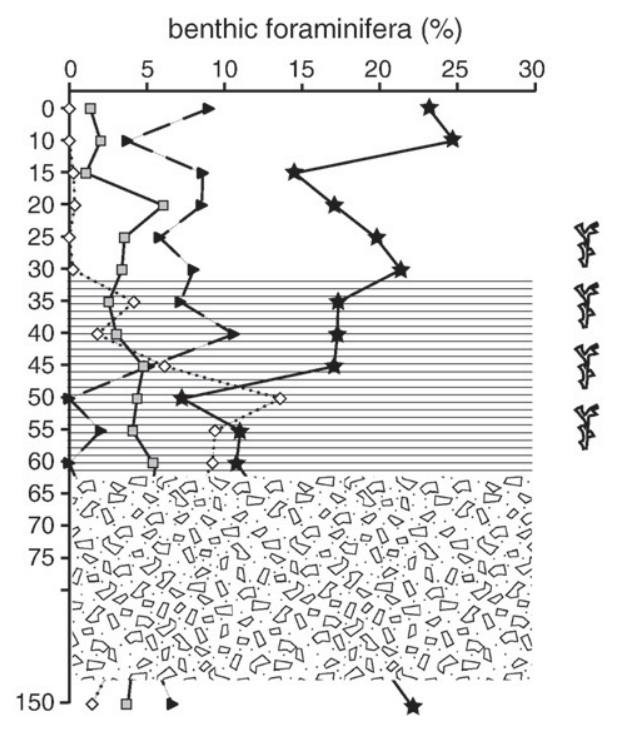

Maya MV

TTR17-MS419G
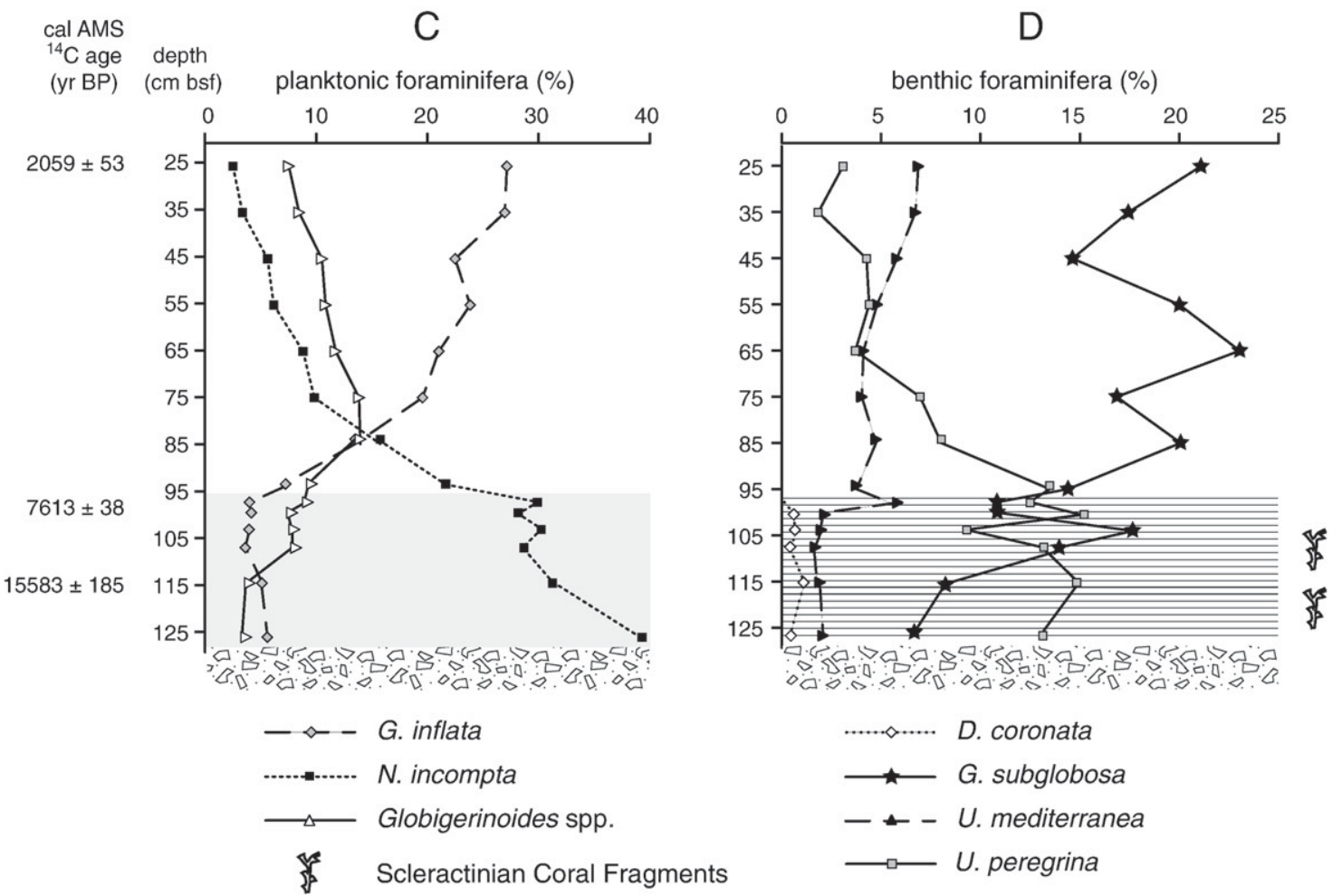

Fig. 2. Relative abundance of the most significant planktonic (A/C) and benthic (B/D) foraminiferal species for the two investigated cores. Shaded areas: G. inflata period in the planktonic foraminiferal assemblage; striped areas: $D$. coronata period in the benthic foraminiferal assemblage; patterned areas: mud breccia level.

containing coral fragments yield an age of $7613 \pm 38$ years BP (Table 2). The sample taken from the hemipelagic drape at $25 \mathrm{~cm}$ is dated at $2059 \pm 53$ years BP. Based on these dates the linear sedimentation rates for the two sites were determined as illustrated in Fig. 4. Lower sedimentation rates of $10.3 \mathrm{~cm} \mathrm{kyr}^{-1}$ and $2.1 \mathrm{~cm} \mathrm{kyr}^{-1}$ correspond to the cold-water coral-rich layers. Higher rates of sedimentation ( $22.7 \mathrm{~cm} \mathrm{kyr}^{-1}$ and $23.9 \mathrm{~cm} \mathrm{kyr}^{-1}$ ) are observed for the hemipelagic drape at Dhaka MV between 0 and $35 \mathrm{~cm}$ and at Maya MV in the uppermost $25 \mathrm{~cm}$ of the hemipelagic part, respectively.

\section{Discussion}

In the Gulf of Cadiz fossil scleractinian corals presently cover more than 20 mud volcanoes (Pinheiro et al., 2003; Somoza et al., 2003; 
A

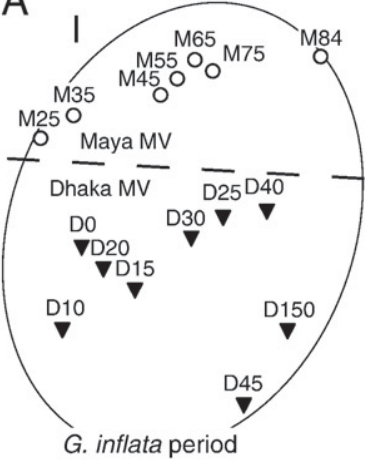

G. inflata period

Dhaka Mud Volcano

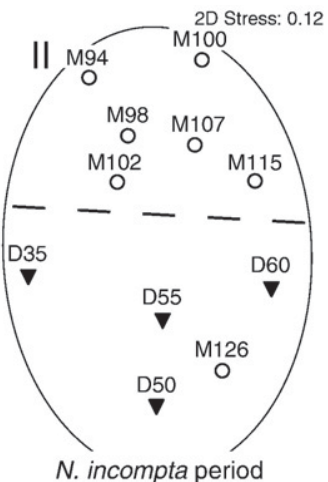

O Maya Mud Volcano
B
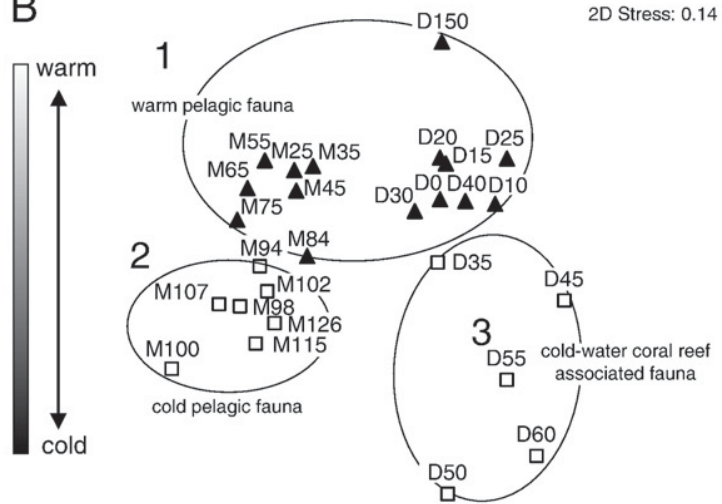

․ N. incompta period

Fig. 3. Non-metric Multi Dimensional Scaling (nMDS) plot obtained from the Bray-Curtis similarity matrix of planktonic and benthic foraminifera compositional data. (A) Planktonic foraminifera clusters (I) G. inflata dominated group (II) N. incompta dominated group (B) Benthic foraminiferal clusters: (1) benthic foraminifera from the G. inflata period (Maya and Dhaka MVs); (2) benthic foraminifera from the N. incompta period (Maya MV); (3) benthic foraminifera from the N. incompta period (Dhaka MV).

Wienberg et al., 2009). Some of them are located along the Spanish margin in water depths between 530 and $1100 \mathrm{~m}$, others are present along the Moroccan margin in a larger water depth range of 420 to $1300 \mathrm{~m}$ (Wienberg et al., 2009). Fossil cold-water corals were also documented in the Strait of Gibraltar (Alvarez-Péréz et al., 2005). However, hardly any detailed study about sedimentary sequences containing fossil cold-water corals from tops of Alboran mud volcanoes was available prior to TTR-17-Leg 1 (Ivanov et al., 2009).

The sediment intervals containing cold-water coral fragments overlay the extruded mud breccia in the Dhaka and Maya MVs. Lacking detailed sedimentological analyses, planktonic and benthic foraminifera faunal assemblages are used to reconstruct the environmental and paleoceanographic settings. Data are compared with existing studies on modern foraminiferal assemblages from cold-water coral reefs and the periods of coral growth and demise on the mud volcanoes in the western Alboran Sea are discussed in relation to published coral ages of that region.

\section{Table 4}

List of planktonic foraminiferal species and statistical parameters associated with the similarity in cluster I to II. Average similarity within the group of station, average abundance, average similarity, contribution (\%), and cumulative contribution (\%) are given for each species with respect to the total similarity for each cluster

\begin{tabular}{|c|c|c|c|c|}
\hline \multicolumn{5}{|l|}{ Cluster I } \\
\hline \multirow[t]{2}{*}{ Species } & \multicolumn{4}{|c|}{ Average similarity: 84.72} \\
\hline & Av.Abund & Av.Sim & Contrib\% & Cum.\% \\
\hline Gr. inflata & 4.72 & 12.61 & 14.89 & 14.89 \\
\hline Tr. quinqueloba & 4.61 & 12.58 & 14.85 & 29.74 \\
\hline Ga. glutinata & 4.05 & 10.58 & 12.49 & 42.23 \\
\hline N. incompta & 3.17 & 7.77 & 9.17 & 51.4 \\
\hline Gs. ruber & 2.78 & 7.57 & 8.93 & 60.33 \\
\hline G. bulloides & 2.74 & 6.97 & 8.23 & 68.56 \\
\hline Gs. elongatus & 1.23 & 3.04 & 3.59 & 72.15 \\
\hline Ga. uvula & 1.27 & 2.99 & 3.53 & 75.68 \\
\hline Tr. humilis & 1.09 & 2.68 & 3.16 & 78.84 \\
\hline \multicolumn{5}{|l|}{ Cluster II } \\
\hline \multirow[t]{2}{*}{ Species } & \multicolumn{4}{|c|}{ Average similarity: 84.15} \\
\hline & Av.Abund & Av.Sim & Contrib\% & Cum.\% \\
\hline Tr. quinqueloba & 5.62 & 17.65 & 20.97 & 20.97 \\
\hline N. incompta & 5.43 & 16.61 & 19.73 & 40.71 \\
\hline Ga. glutinata & 3.92 & 11.95 & 14.2 & 54.9 \\
\hline G. bulloides & 2.19 & 6.51 & 7.73 & 62.64 \\
\hline Gs. ruber & 2.22 & 6.2 & 7.36 & 70 \\
\hline Gr. inflata & 2.12 & 6.01 & 7.15 & 77.14 \\
\hline
\end{tabular}

5.1. Similarities and differences of faunal assemblages between the fossil mud volcano coral reefs, Atlantic and Mediterranean coral reef settings

The distribution pattern of the benthic foraminiferal assemblages in samples from Maya and Dhaka MVs is consistent with the distribution pattern observed in the cold-water coral mounds offshore Ireland. There, benthic foraminiferal assemblages provide an independent tool to identify and describe the different facies related to cold-water coral mounds in the Porcupine Seabight and at the Rockall Bank (Margreth et al., 2009). In particular, the species Discanomalina coronata, associated with other epi- and infaunal species, was identified as a bioindicator for cold-water coral ecosystems, as they typically occur in the living and dead cold-water corals and sandwave facies, while uvigerinids act as an indicator for off-mound sediments (Margreth et al., 2009). In the sediments from Maya and Dhaka MVs, $D$. coronata and the associated benthic assemblage are consistently present in association with coral fragments (Fig. 5; Appendices A and B). The sediments above and below the coral fragment-bearing layer contain the typical off-mound associated benthic foraminiferal assemblage described for the Porcupine Basin and Rockall Bank, which is not abundantly present in the coral-rich levels. A transport or erosion of coral fragments from higher levels can be excluded or occurred only on small, dm-scale, as the sediment cores were recovered from top of both mud volcanoes. This

Table 5

List of planktonic species and statistical parameter associated with the dissimilarity between each pair of clusters I to II. The average dissimilarity is shown. For each species the average abundance, average dissimilarity, contribution (\%), and cumulative contribution (\%) to the total similarity are also given.

\begin{tabular}{|c|c|c|c|c|c|}
\hline \multicolumn{6}{|l|}{ Clusters I and II } \\
\hline \multirow[t]{3}{*}{ Species } & \multicolumn{5}{|c|}{ Average dissimilarity $=23.66$} \\
\hline & \multirow{2}{*}{$\frac{\text { Cluster I }}{\text { Av.Abund }}$} & \multirow{2}{*}{$\frac{\text { Cluster II }}{\text { Av.Abund }}$} & \multirow[b]{2}{*}{ Av.Diss } & \multirow[b]{2}{*}{ Contrib\% } & \multirow[b]{2}{*}{ Cum.\% } \\
\hline & & & & & \\
\hline Gr. inflata & 4.72 & 2.12 & 4.02 & 16.97 & 16.97 \\
\hline N. incompta & 3.17 & 5.43 & 3.55 & 15 & 31.98 \\
\hline Tr. quinqueloba & 4.61 & 5.62 & 1.6 & 6.77 & 38.75 \\
\hline Ga. glutinata & 4.05 & 3.92 & 1.11 & 4.7 & 43.45 \\
\hline G. bulloides & 2.74 & 2.19 & 1.06 & 4.47 & 47.92 \\
\hline Gs. ruber & 2.78 & 2.22 & 1 & 4.25 & 52.17 \\
\hline Ta. rubescens & 1.24 & 0.91 & 0.93 & 3.93 & 56.1 \\
\hline Gs. immaturus & 0.85 & 0.3 & 0.88 & 3.72 & 59.82 \\
\hline Gs. sacculifer & 0.71 & 0.19 & 0.85 & 3.59 & 63.4 \\
\hline N. pachyderma & 0.73 & 0.6 & 0.79 & 3.32 & 66.72 \\
\hline Gs. elongatus & 1.23 & 0.9 & 0.7 & 2.94 & 69.66 \\
\hline Gr. scitula & 0.61 & 0.49 & 0.66 & 2.8 & 72.46 \\
\hline N. dutertrei & 0.29 & 0.5 & 0.66 & 2.77 & 75.23 \\
\hline Tr. humilis & 1.09 & 0.8 & 0.64 & 2.71 & 77.94 \\
\hline
\end{tabular}


Table 6

List of benthic foraminiferal species and statistical parameters associated with the similarity in clusters 1 to 3 . Average similarity within the group of station, average abundance, average similarity, contribution (\%), and cumulative contribution (\%) are given for each species with respect to the total similarity for each cluster.

\begin{tabular}{lllll}
\hline Cluster 1 & \multicolumn{4}{l}{$l$} \\
\hline Species & \multicolumn{4}{l}{ Average similarity: 63.31 } \\
\cline { 2 - 5 } & Av.Abund & Av.Sim & Contrib\% & Cum.\% \\
\hline Globocassidulina subglobosa group & 19.6 & 17.73 & 28 & 28 \\
Uvigerina mediterranea & 5.78 & 4.31 & 6.81 & 34.81 \\
Bolivina difformis & 4.77 & 3.79 & 5.98 & 40.79 \\
Bulimina marginata & 4.8 & 3.71 & 5.86 & 46.65 \\
Uvigerina peregrina & 3.88 & 2.73 & 4.32 & 50.97 \\
Cassidulina carinata & 3.38 & 2.39 & 3.78 & 54.75 \\
Gavelinopsis praegeri & 3.39 & 2.27 & 3.58 & 58.33 \\
Cibicidoides sp. & 2.92 & 1.95 & 3.08 & 61.41 \\
Melonis barleeanum & 2.71 & 1.94 & 3.07 & 64.48 \\
Hyalinea balthica & 2.64 & 1.73 & 2.74 & 67.22 \\
Amphicoryna scalaris & 2.41 & 1.52 & 2.4 & 69.63 \\
Bigenerina nodosaria & 1.86 & 1.3 & 2.05 & 71.67 \\
Hoeglundina elegans & 1.64 & 1.08 & 1.7 & 73.37 \\
Cibicidoides pseudoungerianus & 1.63 & 0.9 & 1.42 & 74.79 \\
Lobatula lobatula & 1.38 & 0.87 & 1.38 & 76.17 \\
Sigmoilopsis schlumbergeri & 1.27 & 0.76 & 1.2 & 77.37 \\
Sphaeroidina bulloides & 1.38 & 0.73 & 1.16 & 78.53 \\
Cassidulina laevigata & 1.35 & 0.65 & 1.03 & 79.56 \\
Quinqueloculina viennensis & 1.25 & 0.65 & 1.03 & 80.59 \\
& & & &
\end{tabular}

Cluster 2

\begin{tabular}{lllll}
\hline \multirow{2}{*}{ Species } & \multicolumn{4}{l}{ Average similarity: 71.06 } \\
\cline { 2 - 5 } & Av.Abund & Av.Sim & Contrib\% & Cum.\% \\
\hline Uvigerina peregrina & 13.09 & 12.01 & 16.9 & 16.9 \\
Globocassidulina subglobosa group & 11.86 & 9.51 & 13.38 & 30.28 \\
Bulimina marginata & 7.97 & 6.87 & 9.66 & 39.94 \\
Hyalinea balthica & 7.14 & 5.71 & 8.03 & 47.98 \\
Melonis barleeanum & 3.99 & 3.21 & 4.52 & 52.5 \\
Amphicoryna scalaris & 3.03 & 2.31 & 3.25 & 55.75 \\
Bulimina striata & 3.03 & 2.28 & 3.21 & 58.97 \\
Cassidulina carinata & 2.96 & 2.25 & 3.16 & 62.13 \\
Uvigerina mediterranea & 2.78 & 2.01 & 2.82 & 64.95 \\
Sigmoilopsis schlumbergeri & 2.16 & 1.82 & 2.56 & 67.51 \\
Cibicidoides pseudoungerianus & 2.02 & 1.72 & 2.42 & 69.94 \\
Sphaeroidina bulloides & 1.94 & 1.41 & 1.98 & 71.92 \\
Bolivina difformis & 1.87 & 1.35 & 1.9 & 73.82 \\
Bulimina aculeata & 1.58 & 1.09 & 1.53 & 75.35 \\
Hoeglundina elegans & 1.4 & 1.04 & 1.46 & 76.81 \\
Spiroplectinella wrighti & 1.31 & 1 & 1.41 & 78.22 \\
Bolivina spathulata & 1.39 & 0.97 & 1.36 & 79.58
\end{tabular}

Cluster 3

\begin{tabular}{lcccc}
\hline \multirow{2}{*}{ Species } & \multicolumn{4}{l}{ Average similarity: 63.23 } \\
\cline { 2 - 5 } & Av.Abund & Av.Sim & Contrib\% & Cum.\% \\
\hline Discanomalina coronata & 10.74 & 9.28 & 14.68 & 14.68 \\
Globocassidulina subglobosa group & 9.69 & 8.44 & 13.36 & 28.04 \\
Bolivina difformis & 5.75 & 4.57 & 7.23 & 35.27 \\
Uvigerina peregrina & 4.61 & 4.18 & 6.61 & 41.88 \\
Cibicidoides sp. & 6.85 & 3.44 & 5.44 & 47.32 \\
Cibicidoides pachyderma & 3.68 & 2.93 & 4.63 & 51.96 \\
Hyalinea balthica & 2.91 & 2.59 & 4.1 & 56.05 \\
Melonis barleeanum & 2.76 & 2.39 & 3.77 & 59.83 \\
Gavelinopsis praegeri & 2.57 & 2.27 & 3.59 & 63.42 \\
Angulogerina angulosa & 2.71 & 2 & 3.16 & 66.58 \\
Bolivina subaenariensis & 2.37 & 1.86 & 2.94 & 69.52 \\
Bulimina marginata & 2.25 & 1.63 & 2.57 & 72.09 \\
Cassidulina carinata & 2.43 & 1.57 & 2.48 & 74.57 \\
Cassidulina laevigata & 2.92 & 1.57 & 2.48 & 77.05 \\
Lobatula lobatula & 2.21 & 1.24 & 1.96 & 79.02 \\
Cibicidoides pseudoungerianus & 1.65 & 1.16 & 1.83 & 80.85 \\
\hline
\end{tabular}

indicates that the corals were living in situ on top of the mud breccia. The fragmentation of the corals may be a later effect of bioerosion (e.g. Beuck et al., 2010) and/or a change in ambient chemistry associated with burial leading to partial dissolution of aragonite, which was also related to the strong alteration and dissolution of coral fragments sampled at various sites in the Gulf of Cadiz (Kopf et al., 2004; Foubert et al., 2008).

The basic requirements for the settlement and growth of cold-water corals are suitable substrates, supply of nutrients and low sedimentation rates in a hydrodynamic environment with long and stable (cool) water temperature conditions (e.g., Frederiksen et al., 1992; Rogers, 1999; De Mol et al., 2002; Freiwald, 2002; Freiwald et al., 2004; Alvarez-Péréz et al., 2005; Roberts et al., 2006). Recently, Dullo et al. (2008) documented that cold-water corals in the Atlantic can adapt to a wide range of environmental conditions (temperature, salinity, dissolved oxygen) but they only thrive in seawater densities (sigma-theta, $\sigma_{\Theta}$ ) between 27.35 and $27.65 \mathrm{~kg} \mathrm{~m}^{-3}$. The limiting density in the Mediterranean Sea is $29.10 .03 \mathrm{~kg} \mathrm{~m}^{-3}$ (Freiwald et al., 2009). This Mediterranean seawater density value comprises the boundary between light and dense Mediterranean Water at $29.08 \mathrm{~kg} \mathrm{~m}^{-3}$ (Millot, 2009). Based on CTD data collected close to the investigated mud volcanoes $\left(35^{\circ} 30^{\prime} \mathrm{N}, 4^{\circ} 30^{\prime} \mathrm{W}\right)$ today's boundary between the two water masses is approximately at $430 \mathrm{~m}$. However, it seasonally varies during the course of a year (Millot, 2009), but seems to be slightly too deep for corals to grow on the two investigated mud volcanoes at $370 \mathrm{~m}$ (Dhaka) and $410 \mathrm{~m}$ water depth (Maya). Rogerson et al. (2008) show a shoaling of the interface between these light (intermediate) and dense (deep) waters during the time of deglaciation suggesting that the preferential depths of cold-water coral growth decreased. McCulloch et al. (2010) discuss a decrease in salinity (and therefore seawater density) during the YD and post-YD periods as glacial freshwater input made conditions more conducive for cold-water corals to develop. Nevertheless, as pointed out by Dullo et al. (2008) seawater density alone does not define the occurrence of deep-sea corals; other, closely related parameters such as nutrient levels are of importance (McCulloch et al., 2010).

At the mud volcanoes in the Alboran Sea, the availability of similar substratum, low sedimentation rates, relatively long duration of stable environmental conditions and similar density values seem to be a common feature. León et al. (2007) suggested that colonization of mud volcanoes by non-chemosynthetic organisms such as corals might be related to periods of slow seepage activity inducing the formation of carbonate crusts. Sediment cores from various mud volcanoes in the Gulf of Cadiz show sequences of mud breccia with intercalation of intervals rich in cold-water coral debris (Akhmetzhanov et al., 2007; Foubert et al., 2008). However, no carbonate crusts are observed in the cores from Dhaka and Maya MVs. Sediment cores from IODP Expedition 307 also indicate a firm ground being suitable as substrate for coral growth initiation (Ferdelman et al., 2006). Furthermore, in the northern Ionian Sea of the Mediterranean, the Lophelia reefs off Santa Maria di Leuca are another example of successful colonization of a prevalently non-rocky substratum on a gently sloping margin (Taviani et al., 2005), indicating that suitable substrates are not necessarily "hard" or solid. Therefore, also at Dhaka and Maya MVs lithified and semi-lithified clay clasts of the mud breccia may have acted as nucleation points and suitable substrate for cold-water coral colonization (Fig. 2).

An elevated position is additionally of importance for these structures to facilitate the development of coral reefs (Masson et al., 2003). AMS ${ }^{14} \mathrm{C}$ dates indicate that the duration of cold-water coral colonization may have lasted around 2000 years at Dhaka and 7000 years at Maya MV according to the distribution of coral fragments and typical cold-water coral-associated benthic foraminiferal fauna (Figs. 5 and 6). These time spans appear to be long enough for allowing the stabilization of the favorable paleoceanographic conditions that concurred to the colonization of the newly suitable substratum offered by the extruded mud breccia and to the consequent coral development. Low sedimentation rates due to stronger currents are one of the favorable factors for coldwater coral ecosystem development, as corals must sufficiently keep-up with hemipelagic sedimentation (Huvenne et al., 2002; Dorschel et al., 2005; Rüggeberg et al., 2005, 2007). In both mud volcanoes the coral-rich layer correspond to lower sedimentation rate values, e.g. $10.3 \mathrm{~cm} \mathrm{kyr}^{-1}$ for Dhaka and $2.1 \mathrm{~cm} \mathrm{kyr}^{-1}$ for Maya MV, respectively (Fig. 4). 
Table 7

List of benthic species and statistical parameter associated with the dissimilarity between each pair of clusters 1 to 3 . For each pair of clusters the average dissimilarity is shown. For each species the average abundance, average dissimilarity, contribution (\%), and cumulative contribution (\%) to the total similarity are also given.

\begin{tabular}{|c|c|c|c|c|c|}
\hline \multicolumn{6}{|l|}{ Cluster 1 and 2} \\
\hline \multirow[t]{3}{*}{ Species } & \multicolumn{5}{|c|}{ Average dissimilarity $=45.19$} \\
\hline & \multirow{2}{*}{$\frac{\text { Cluster } 1}{\text { Av.Abund }}$} & \multicolumn{4}{|l|}{ Cluster 2} \\
\hline & & Av.Abund & Av.Diss & Contrib\% & Cum.\% \\
\hline Uvigerina peregrina & 3.88 & 13.09 & 4.61 & 10.19 & 10.19 \\
\hline Globocassidulina subglobosa group & 19.6 & 11.86 & 3.95 & 8.75 & 18.94 \\
\hline Hyalinea balthica & 2.64 & 7.14 & 2.31 & 5.12 & 24.05 \\
\hline Uvigerina mediterranea & 5.78 & 2.78 & 1.73 & 3.84 & 27.89 \\
\hline Bulimina marginata & 4.8 & 7.97 & 1.71 & 3.78 & 31.68 \\
\hline Bolivina difformis & 4.77 & 1.87 & 1.48 & 3.27 & 34.95 \\
\hline Gavelinopsis praegeri & 3.39 & 1.08 & 1.22 & 2.69 & 37.64 \\
\hline Bulimina striata & 0.76 & 3.03 & 1.13 & 2.51 & 40.15 \\
\hline Cibicidoides sp. & 2.92 & 1.12 & 0.96 & 2.12 & 42.27 \\
\hline Melonis barleeanum & 2.71 & 3.99 & 0.91 & 2.02 & 44.29 \\
\hline Cassidulina carinata & 3.38 & 2.96 & 0.83 & 1.83 & 46.11 \\
\hline Amphicoryna scalaris & 2.41 & 3.03 & 0.79 & 1.76 & 47.87 \\
\hline Cassidulina laevigata & 1.35 & 1.42 & 0.64 & 1.42 & 49.29 \\
\hline Sphaeroidina bulloides & 1.38 & 1.94 & 0.63 & 1.4 & 50.69 \\
\hline Discanomalina coronata & 1.18 & 0.38 & 0.62 & 1.38 & 52.07 \\
\hline Cibicidoides pseudoungerianus & 1.63 & 2.02 & 0.59 & 1.3 & 53.38 \\
\hline Bulimina aculeata & 0.57 & 1.58 & 0.56 & 1.23 & 54.61 \\
\hline Sigmoilopsis schlumbergeri & 1.27 & 2.16 & 0.55 & 1.22 & 55.83 \\
\hline Bigenerina nodosaria & 1.86 & 1.19 & 0.55 & 1.21 & 57.03 \\
\hline Gyroidina altiformis & 0.81 & 1.08 & 0.52 & 1.14 & 58.18 \\
\hline Quinqueloculina viennensis & 1.25 & 0.44 & 0.51 & 1.12 & 59.3 \\
\hline Lobatula lobatula & 1.38 & 1.35 & 0.5 & 1.11 & 60.4 \\
\hline Cibicidoides pachyderma & 1.06 & 0.16 & 0.49 & 1.09 & 61.49 \\
\hline Hoeglundina elegans & 1.64 & 1.4 & 0.47 & 1.03 & 62.53 \\
\hline Gyroidina neosoldanii & 1.24 & 0.63 & 0.46 & 1.02 & 63.55 \\
\hline Bolivina spathulata & 1.18 & 1.39 & 0.46 & 1.02 & 64.57 \\
\hline Spiroplectinella wrighti & 1.09 & 1.31 & 0.44 & 0.97 & 65.54 \\
\hline Melonis pompilioides & 0.45 & 1.21 & 0.42 & 0.94 & 66.48 \\
\hline Bolivina dilatata & 0.84 & 1.23 & 0.42 & 0.93 & 67.41 \\
\hline Bolivina suspinescens & 0.41 & 1.05 & 0.4 & 0.89 & 68.3 \\
\hline Cibicides refulgens & 0.71 & 0.44 & 0.4 & 0.89 & 69.19 \\
\hline Bolivina striatula & 0.34 & 1.05 & 0.4 & 0.88 & 70.07 \\
\hline Cibicidoides kullenbergi & 1.06 & 0.57 & 0.38 & 0.84 & 70.91 \\
\hline Planulina ariminensis & 0.56 & 0.96 & 0.37 & 0.82 & 71.73 \\
\hline Nuttalides umboniferus & 0.72 & 0 & 0.36 & 0.79 & 72.52 \\
\hline Globobulimina affinis & 0.81 & 0.57 & 0.35 & 0.77 & 73.29 \\
\hline Rectuvigerina elongatastriata & 0.72 & 0.05 & 0.35 & 0.77 & 74.06 \\
\hline Angulogerina angulosa & 0.66 & 0.57 & 0.34 & 0.75 & 74.81 \\
\hline Textularia agglutinans & 0.69 & 0.03 & 0.33 & 0.74 & 75.55 \\
\hline Lenticulina inornata & 0.74 & 0.22 & 0.33 & 0.73 & 76.28 \\
\hline Bolivina subaenariensis & 0.12 & 0.67 & 0.31 & 0.68 & 76.96 \\
\hline Discorbinella bertheloti & 0.42 & 0.74 & 0.3 & 0.67 & 77.63 \\
\hline Hanzawaia boueana & 0.91 & 0.45 & 0.3 & 0.67 & 78.31 \\
\hline Cycloforina laevigata & 0.31 & 0.6 & 0.3 & 0.67 & 78.98 \\
\hline Rosalina globularis & 0.67 & 0.51 & 0.29 & 0.64 & 79.62 \\
\hline \multicolumn{6}{|l|}{ Cluster 1 and 3} \\
\hline \multirow[t]{3}{*}{ Species } & \multicolumn{5}{|c|}{ Average dissimilarity $=50.06$} \\
\hline & Cluster 1 & Cluster 3 & & & \\
\hline & $\overline{\text { Av.Abund }}$ & $\overline{\text { Av.Abund }}$ & Av.Diss & Contrib\% & Cum.\% \\
\hline Globocassidulina subglobosa group & 19.6 & 9.69 & 4.96 & 9.9 & 9.9 \\
\hline Discanomalina coronata & 1.18 & 10.74 & 4.78 & 9.55 & 19.45 \\
\hline Uvigerina mediterranea & 5.78 & 0.68 & 2.57 & 5.14 & 24.59 \\
\hline Cibicidoides sp. & 2.92 & 6.85 & 2.27 & 4.54 & 29.12 \\
\hline Cibicidoides pachyderma & 1.06 & 3.68 & 1.33 & 2.65 & 31.77 \\
\hline Bulimina marginata & 4.8 & 2.25 & 1.31 & 2.63 & 34.4 \\
\hline Bolivina subaenariensis & 0.12 & 2.37 & 1.12 & 2.24 & 36.64 \\
\hline Cassidulina laevigata & 1.35 & 2.92 & 1.07 & 2.14 & 38.78 \\
\hline Bolivina difformis & 4.77 & 5.75 & 1.03 & 2.06 & 40.84 \\
\hline Angulogerina angulosa & 0.66 & 2.71 & 1.03 & 2.06 & 42.9 \\
\hline Uvigerina peregrina & 3.88 & 4.61 & 0.92 & 1.83 & 44.73 \\
\hline Cassidulina carinata & 3.38 & 2.43 & 0.89 & 1.79 & 46.52 \\
\hline Bigenerina nodosaria & 1.86 & 0.14 & 0.87 & 1.74 & 48.26 \\
\hline Gavelinopsis praegeri & 3.39 & 2.57 & 0.84 & 1.68 & 49.93 \\
\hline Amphicoryna scalaris & 2.41 & 1.04 & 0.81 & 1.61 & 51.55 \\
\hline Cibicides refulgens & 0.71 & 1.49 & 0.74 & 1.49 & 53.03 \\
\hline Marginulina subalata & 0.06 & 1.46 & 0.74 & 1.48 & 54.51 \\
\hline Hyalinea balthica & 2.64 & 2.91 & 0.69 & 1.38 & 55.89 \\
\hline
\end{tabular}


Table 7 (continued)

Cluster 1 and 3

\begin{tabular}{|c|c|c|c|c|c|}
\hline \multirow[t]{3}{*}{ Species } & \multicolumn{5}{|c|}{ Average dissimilarity $=50.06$} \\
\hline & \multirow{2}{*}{$\frac{\text { Cluster } 1}{\text { Av.Abund }}$} & \multicolumn{4}{|l|}{ Cluster 3} \\
\hline & & Av.Abund & Av.Diss & Contrib\% & Cum.\% \\
\hline Lobatula lobatula & 1.38 & 2.21 & 0.68 & 1.37 & 57.25 \\
\hline Bolivina spathulata & 1.18 & 0.95 & 0.68 & 1.37 & 58.62 \\
\hline Pyrgo anomala & 0.08 & 1.3 & 0.64 & 1.27 & 59.89 \\
\hline Bulimina aculeata & 0.57 & 1.66 & 0.63 & 1.25 & 61.14 \\
\hline Quinqueloculina viennensis & 1.25 & 0.73 & 0.62 & 1.24 & 62.39 \\
\hline Cibicidoides pseudoungerianus & 1.63 & 1.65 & 0.59 & 1.17 & 63.56 \\
\hline Hoeglundina elegans & 1.64 & 1.55 & 0.59 & 1.17 & 64.73 \\
\hline Sigmoilopsis schlumbergeri & 1.27 & 0.16 & 0.58 & 1.16 & 65.89 \\
\hline Sphaeroidina bulloides & 1.38 & 0.65 & 0.56 & 1.12 & 67.01 \\
\hline Melonis barleeanum & 2.71 & 2.76 & 0.55 & 1.11 & 68.11 \\
\hline Miliolinella subrotunda & 0.46 & 1.36 & 0.55 & 1.1 & 69.21 \\
\hline Spiroplectinella wrighti & 1.09 & 0.26 & 0.49 & 0.98 & 70.19 \\
\hline Gyroidina neosoldanii & 1.24 & 0.68 & 0.49 & 0.97 & 71.16 \\
\hline Cibicidoides kullenbergi & 1.06 & 1.35 & 0.47 & 0.93 & 72.1 \\
\hline Hanzawaia boueana & 0.91 & 1.57 & 0.44 & 0.88 & 72.98 \\
\hline Bolivina dilatata & 0.84 & 1.3 & 0.41 & 0.82 & 73.8 \\
\hline Gyroidina altiformis & 0.81 & 0 & 0.4 & 0.81 & 74.61 \\
\hline Globobulimina affinis & 0.81 & 0.14 & 0.37 & 0.74 & 75.34 \\
\hline Gyroidina soldanii & 0.5 & 0.84 & 0.37 & 0.73 & 76.08 \\
\hline Rectuvigerina elongatastriata & 0.72 & 0 & 0.36 & 0.72 & 76.8 \\
\hline Textularia agglutinans & 0.69 & 0 & 0.34 & 0.68 & 77.48 \\
\hline Nuttalides umboniferus & 0.72 & 0.08 & 0.34 & 0.67 & 78.15 \\
\hline Fissurina marginata & 0.09 & 0.73 & 0.33 & 0.66 & 78.82 \\
\hline Lenticulina inornata & 0.74 & 0.26 & 0.33 & 0.66 & 79.48 \\
\hline \multicolumn{6}{|l|}{ Cluster 2 and 3} \\
\hline \multirow[t]{3}{*}{ Species } & \multicolumn{5}{|c|}{ Average dissimilarity $=54.15$} \\
\hline & Cluster 2 & \multicolumn{4}{|l|}{ Cluster 3} \\
\hline & Av.Abund & Av.Abund & Av.Diss & Contrib\% & Cum.\% \\
\hline Discanomalina coronata & 0.38 & 10.74 & 5.18 & 9.56 & 9.56 \\
\hline Uvigerina peregrina & 13.09 & 4.61 & 4.24 & 7.83 & 17.39 \\
\hline Cibicidoides sp. & 1.12 & 6.85 & 2.86 & 5.28 & 22.68 \\
\hline Bulimina marginata & 7.97 & 2.25 & 2.86 & 5.28 & 27.96 \\
\hline Hyalinea balthica & 7.14 & 2.91 & 2.12 & 3.91 & 31.87 \\
\hline Bolivina difformis & 1.87 & 5.75 & 1.94 & 3.58 & 35.45 \\
\hline Globocassidulina subglobosa group & 11.86 & 9.69 & 1.78 & 3.29 & 38.74 \\
\hline Cibicidoides pachyderma & 0.16 & 3.68 & 1.76 & 3.25 & 41.99 \\
\hline Bulimina striata & 3.03 & 0.73 & 1.15 & 2.12 & 44.11 \\
\hline Angulogerina angulosa & 0.57 & 2.71 & 1.1 & 2.03 & 46.14 \\
\hline Uvigerina mediterranea & 2.78 & 0.68 & 1.07 & 1.98 & 48.12 \\
\hline Amphicoryna scalaris & 3.03 & 1.04 & 1 & 1.85 & 49.97 \\
\hline Sigmoilopsis schlumbergeri & 2.16 & 0.16 & 1 & 1.85 & 51.82 \\
\hline Cassidulina laevigata & 1.42 & 2.92 & 1 & 1.84 & 53.66 \\
\hline Bolivina subaenariensis & 0.67 & 2.37 & 0.85 & 1.57 & 55.23 \\
\hline Melonis barleeanum & 3.99 & 2.76 & 0.78 & 1.44 & 56.67 \\
\hline Cassidulina carinata & 2.96 & 2.43 & 0.75 & 1.38 & 58.05 \\
\hline Gavelinopsis praegeri & 1.08 & 2.57 & 0.75 & 1.38 & 59.43 \\
\hline Marginulina subalata & 0 & 1.46 & 0.73 & 1.34 & 60.77 \\
\hline Sphaeroidina bulloides & 1.94 & 0.65 & 0.71 & 1.31 & 62.08 \\
\hline Bolivina spathulata & 1.39 & 0.95 & 0.71 & 1.31 & 63.39 \\
\hline Lobatula lobatula & 1.35 & 2.21 & 0.69 & 1.27 & 64.66 \\
\hline Cibicides refulgens & 0.44 & 1.49 & 0.67 & 1.24 & 65.9 \\
\hline Pyrgo anomala & 0.06 & 1.3 & 0.64 & 1.18 & 67.08 \\
\hline Bulimina aculeata & 1.58 & 1.66 & 0.58 & 1.07 & 68.14 \\
\hline Miliolinella subrotunda & 0.23 & 1.36 & 0.57 & 1.05 & 69.2 \\
\hline Hanzawaia boueana & 0.45 & 1.57 & 0.57 & 1.05 & 70.25 \\
\hline Spiroplectinella wrightii & 1.31 & 0.26 & 0.56 & 1.04 & 71.29 \\
\hline Gyroidina altiformis & 1.08 & 0 & 0.54 & 1 & 72.28 \\
\hline Bigenerina nodosaria & 1.19 & 0.14 & 0.53 & 0.98 & 73.27 \\
\hline Hoeglundina elegans & 1.4 & 1.55 & 0.53 & 0.97 & 74.24 \\
\hline Bolivina suspinescens & 1.05 & 0 & 0.52 & 0.97 & 75.21 \\
\hline Melonis pompilioides & 1.21 & 0.24 & 0.49 & 0.91 & 76.11 \\
\hline Cibicidoides kullenbergi & 0.57 & 1.35 & 0.46 & 0.84 & 76.95 \\
\hline Planulina ariminensis & 0.96 & 0.08 & 0.44 & 0.81 & 77.76 \\
\hline Quinqueloculina viennensis & 0.44 & 0.73 & 0.44 & 0.81 & 78.57 \\
\hline Spiroloculina excavata & 0 & 0.87 & 0.43 & 0.8 & 79.37 \\
\hline
\end{tabular}



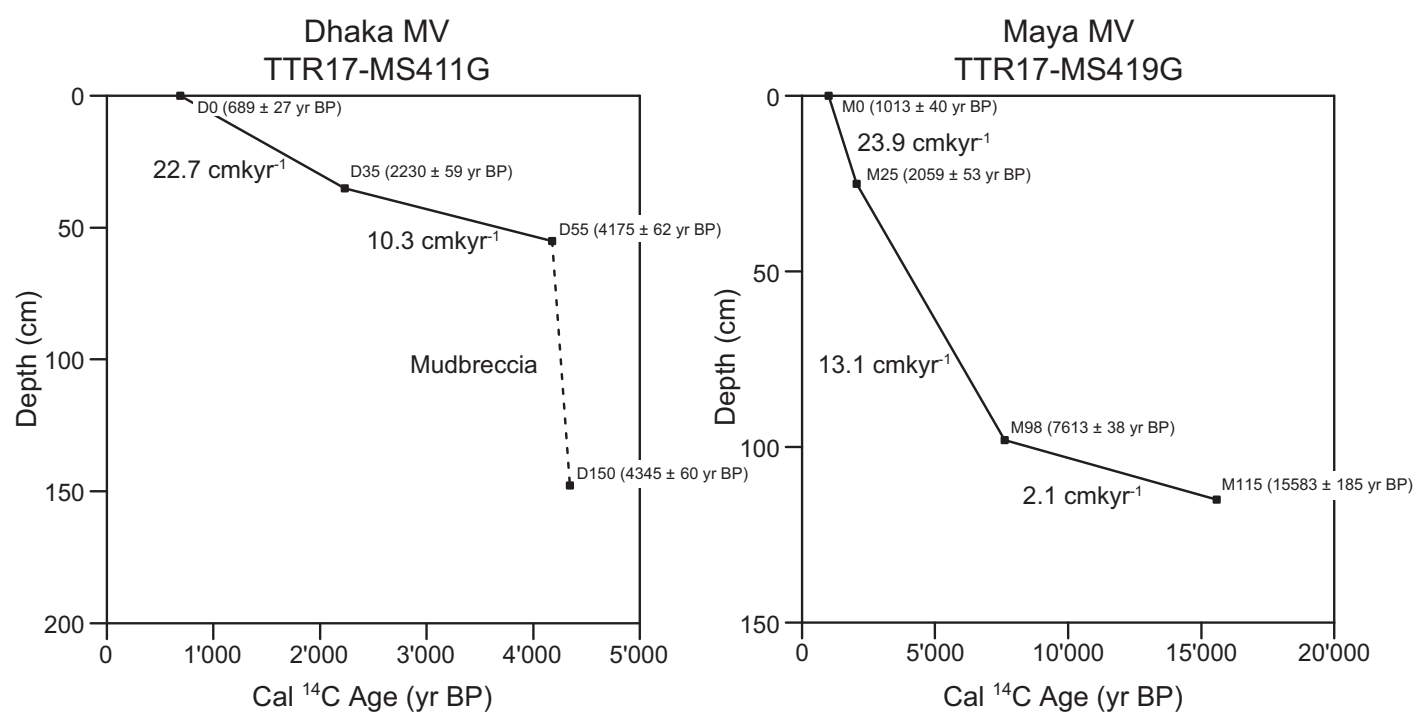

Fig. 4. Calibrated ${ }^{14} \mathrm{C}$ ages (reservoir corrected) versus depth and sedimentation rates in cores TTR17-MS411G (Dhaka MV) and TTR17-MS419G (Maya MV).

5.2. Periods of cold-water coral development on mud volcanoes in the Alboran Sea

A preliminary indication of similarity between the paleoceanographic conditions during the deposition of the sedimentary succession on top of the mud breccia of both mud volcanoes is given by the nMDS plots obtained with multivariate statistical analysis of the foraminiferal data set. In particular a G. inflata dominated period and a $N$. incompta dominated period are clearly discriminated and distinct at both sites (Fig. 3A; Tables 4 and 5). They indicate two different climatic and oceanographic periods in the western Alboran Sea. Additionally, benthic foraminifera show clear separation in both mud volcanoes according to (1) a warmer pelagic fauna (G. inflata period) dominated by G. subglobosa, $U$. mediterranea, B. marginata, and B. difformis, and common for the two mud volcanoes. (2) A cold pelagic fauna ( $N$. incompta period) dominated by U. peregrina, G. subglobosa, B. marginata, and H. balthica at Maya MV, and (3) a cold-water fauna ( $N$. incompta period) associated to cold-water corals and dominated by $B$. difformis, $U$. peregrina, Cibicidoides spp., and $D$. coronata at Dhaka MV (Figs. 3B and 5; Tables 6 and 7). Therefore, since the cold-water corals development on the two mud volcanoes occurred at different times, we discuss the two settings separately to assess, if these ecosystems responded to similar paleoceanographic settings and if a causal link to more extended or even global paleoceanographic events exists.

\subsubsection{Maya mud volcano}

An indication of the paleoceanographic conditions of surface waters can be obtained by the distribution patterns of planktonic foraminiferal assemblages. The sediments corresponding to the coralrich layer span a time interval from slightly older than 15583 \pm 185 years BP to $7613 \pm 38$ years BP. They were deposited on the top of the mud breccia and are dominated by $N$. incompta with very low contribution of warm water species, e.g., Globigerinoides spp. (Figs. 2C and 3A; Tables 4 and 5). This time interval corresponds to the deglaciation including the Bølling-Allerød period, the Younger Dryas, and the Early Holocene (Fig. 6). These sediments also contain a few specimens of $D$. coronata, U. peregrina, B. marginata, $H$. balthica, and A. angulosa (Fig. 3B; Tables 6, 7). This assemblage indicates an environment characterized by enhanced nutrient supply to the surface of the Alboran Sea (e.g., Rogerson et al., 2008) and by cool and nutrient-rich waters at the sea floor, as corroborated by high total organic carbon values in the Alboran deep basin (e.g., Jimenez-Espejo et al., 2008; Rogerson et al., 2008). At present, the Alboran Sea is considered as one of the highest productivity areas associated with upwelling activity (Morel, 1991; Jimenez-Espejo et al., 2008) in the otherwise oligotrophic Mediterranean Sea (Cruzado, 1985). The occurrence of a few specimens of $D$. coronata indeed, underlines the presence of cold-water corals following its interpretation as an indicator species (Margreth et al., 2009). However, its low contribution may point to a reef of limited extension, but in coral facies of the Santa Maria di Leuca coral reefs, Rosso et al. (2010) also observe $D$. coronata only accessory with $<1 \%$ of the total assemblage. It is obvious that the state of coral reefs in the Mediterranean is different from that observed in the Atlantic with less biodiversity (Taviani et al., 2005; Mastrototaro et al., 2010) and being at the limit of environmental stress, especially temperature. Similar findings from the Skagerrak support this interpretation. There, the small coral reefs are under the influence of the isostatic balance of the glacial rebound of Scandinavia lifting the lithosphere and bringing the corals continuously under the influence of the low-saline Baltic water (e.g., Lambeck et al., 1998). Foraminiferal assemblages in the coral facies have only a small contribution of $D$. coronata, which indicates that the abundance of this species mirrors similar ecological requirements as the corals.

The early Holocene is characterized by fresh and wet conditions in the Mediterranean region based on isotope studies on speleothems (e.g., Frisia et al., 2006; Zanchetta et al., 2007). According to JimenezEspejo et al. (2008) and Pérez-Folgado et al. (2003) these conditions ended between $\sim 7.7$ and $\sim 7.2 \mathrm{ka}$ BP, when a major oceanographic change occurred, giving rise to the modern setting of eddies and frontal circulation patterns of the Western Mediterranean Sea. The abundance curve of $N$. incompta from Maya MV reverses its trend with respect to the Globigerinoides spp. and G. inflata at $85 \mathrm{~cm}, 13 \mathrm{~cm}$ above the sample dated with $7613 \pm 38$ years BP (Fig. 2C). A similar reversal was also observed at about $8 \mathrm{ka}$ by Rohling et al. (1995) and at 7/8 ka by Rohling and De Rijk (1999), and was attributed to a deepening and strengthening of the pycnocline/nutricline between the AW and the light MW due to the onset of modern oceanographic conditions (Fairbanks and Wiebe, 1980; Fairbanks et al., 1982; Reynolds and Thunell, 1986; Weaver and Pujol, 1988; Sautter and Thunell, 1989; Rohling et al., 1995). Our data confirm the age of the circulation shift and allow linking it to the end of the African Humid Period with precipitation decline and aridification, which started as early as 7-8 ka in many North African areas (Liu et al., 2007). The slight discrepancy in the age between this study and literature may be due to two factors: 1) an additional reversal younger than that observed in Rohling et al. (1995) cannot be ruled out; and 2) Rohling et al. (1995) 

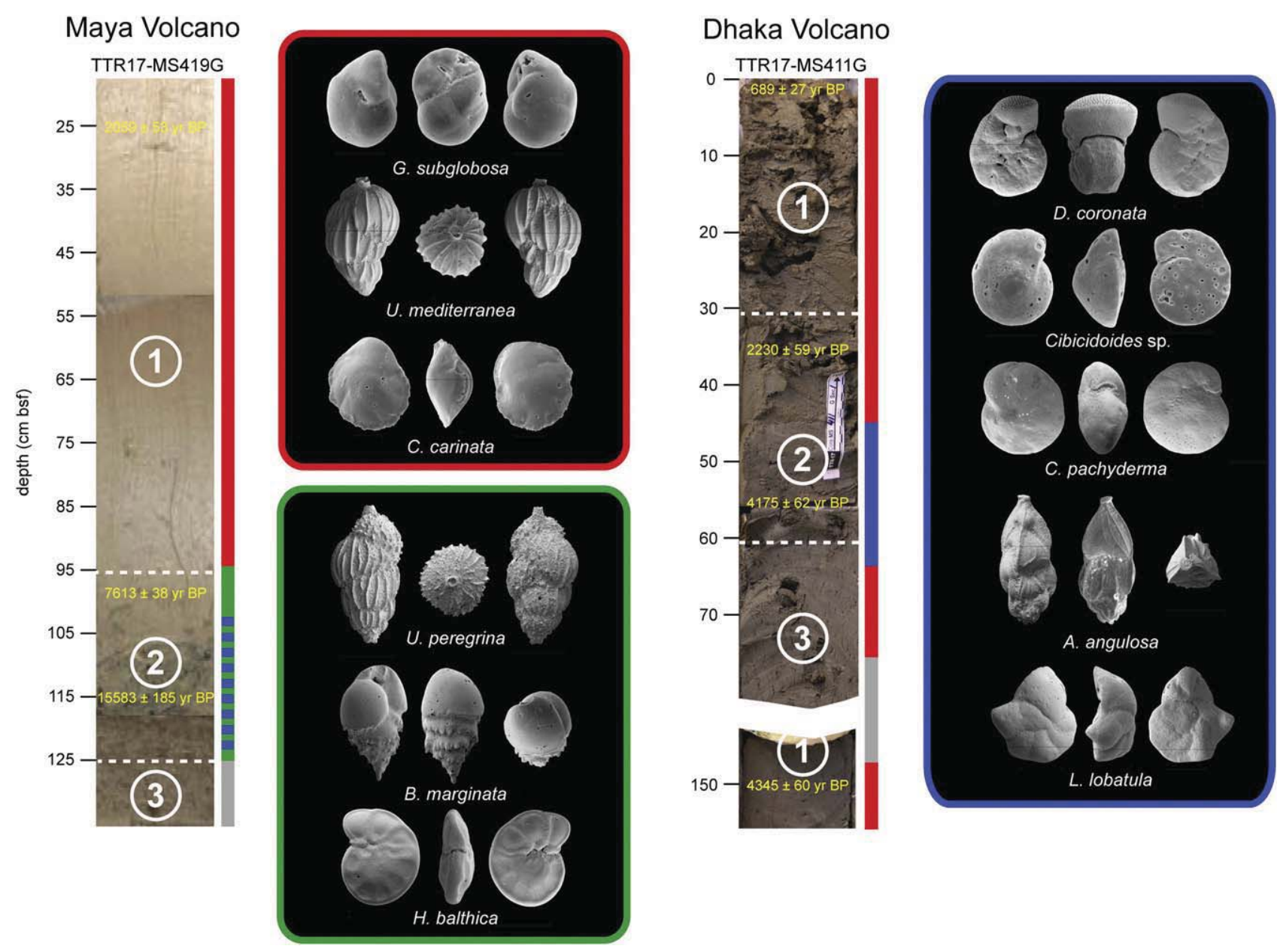

Fig. 5. Benthic foraminiferal assemblages derived from the three nMDS clusters in cores TTR17-MS411G (Dhaka MV) and TTR17-MS419G (Maya MV). Red: pelagic benthic foraminiferal community; green: pelagic sediments with a higher nutrient supply and higher abundance of low oxygen tolerable foraminifera; blue: attached-epifaunal species typically associated to cold-water coral reefs. 1) G. inflata period, 2) N. incompta period, 3) mud breccia. (For interpretation of the references to color in this figure legend, the reader is referred to the web version of this article.)

derive their age model on core KS310, eastern Alboran Sea $\left(36^{\circ} 25^{\prime} \mathrm{N}\right.$, $\left.2^{\circ} 05^{\prime} \mathrm{W}\right)$, from three non-calibrated data points obtained by Pujol and Vergnaud-Grazzini (1989) on core KS8232, adjacent to core KS310. The hemipelagic drape above the interval, where the reversal of N. incompta occurs, contains dominant G. inflata and reflects paleoceanographic conditions more similar to the modern ones with a relatively deep pycnocline between AW and light MW ( $200 \mathrm{~m})$ and a surface layer containing actively meandering jets of Atlantic Waters (Rohling et al., 1995).

\subsubsection{Dhaka mud volcano}

The coral-rich interval at Dhaka MV developed between $4175 \pm 62$ and $2230 \pm 59$ years BP and contains planktonic and benthic foraminiferal assemblages similar to those observed at Maya MV. Planktonic assemblages are dominated by $N$. incompta, suggesting a shallow pycnocline/nutricline and high nutrient availability (Figs. 2A and $3 \mathrm{~A}$ ). The benthic foraminiferal assemblages contain abundantly the coldwater coral associated D. coronata (Margreth et al., 2009), together with other epifaunal species and $A$. angulosa. The presence of this species points towards an environment characterized by high energy and strong currents (Mackensen et al., 1985), important for the lateral transport of sufficient fresh food particles to the suspension feeding cold-water corals (Frederiksen et al., 1992) and conducive of their development and growth (e.g., Roberts et al., 2006). This assemblage composition together with high abundances of $D$. coronata is comparable to those from the Atlantic cold-water coral reefs/mounds (Margreth et al., 2009) or the high-energy environments in the Gulf of
Cadiz (Schönfeld, 2002). Low diversity and low abundance of $D$. coronata at Maya MV are consistent with the reef facies at Santa Maria di Leuca (Rosso et al., 2010).

The shift between the $N$. incompta and the G. inflata dominated assemblages is less abrupt at Dhaka than at Maya MV and is observed at about $30 \mathrm{~cm}(\sim 2230 \pm 59$ years BP $)$. The interpretation of this passage from high productivity and shallow pycno/nutricline to a more modern system dominated by less nutrient supply and a deeper pycno/nutricline is more difficult to explain with respect to the older event documented at Maya MV. Pollen records identify a progressive climatic aridity along the Mediterranean coasts between 6000 and 4000 years BP, roughly corresponding to the end of the African Humid Period at 5500 years BP, with dry conditions observed in the continental records (Barriendos and Martin-Vide, 1998; De Menocal et al., 2000; Swezey, 2001; Liu et al., 2007). At about 4000 years BP the progressive development of complex human society occurred along the Mediterranean coasts (Roberts, 1989) resulting in a drastic anthropogenic-related change in the natural vegetation in the Eastern Mediterranean Sea. This change is clearly detectable in pollen diagrams (Van Zeist et al., 1975) and culminating at about 3400 to 2400 years BP (Roberts, 1989; Baruch, 1994). Riehl (2009) observed consistent changes in vegetation at about 2000 years $\mathrm{BP}$ in correlation to increased aridity along the Eastern Mediterranean coasts. The desiccation and the reduced vegetation cover might cause enhanced erosion and could be responsible for the higher sediment input, indicated by high linear sedimentation rates on both MVs at around 2000 years BP. Therefore, this early human impact, mainly recorded in the Eastern Mediterranean, may have also affected the 


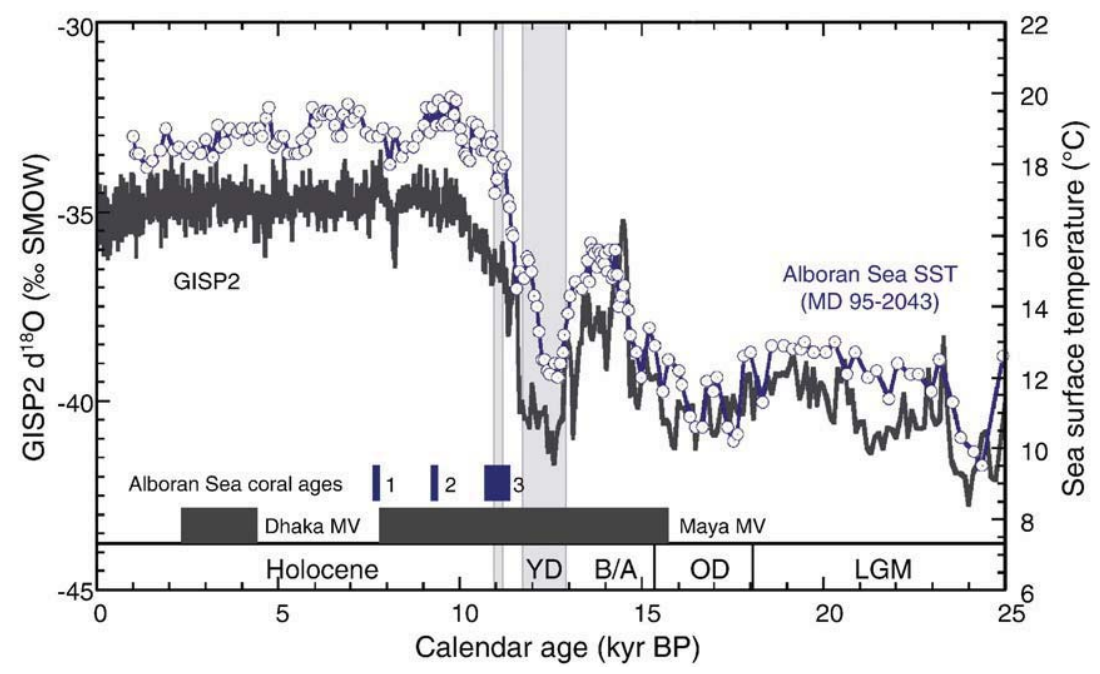

Fig. 6. Distribution of deep-sea corals on Maya and Dhaka mud volcanoes (gray boxes) in comparison with published cold-water coral ages in blue from 1 ) central Alboran Sea (SchröderRitzrau et al., 2005) and 2) and 3) from northeastern Alboran Sea (McCulloch et al., 2010). Left axis indicates $\delta^{18}$ O values of the GISP2 Greenland ice core (Cuffey and Clow, 1997) compared to the SST from the Mediterranean core MD 95-2043 (Cacho et al., 2001; Siani et al., 2001) (right axis). Gray bars indicate cool phases of Younger Dryas and Alboran Sea Cooling Event 5 at around 11 kyr BP. YD = Younger Dryas, B/A=Bølling-Allerød, OD=Older Dryas, LGM=Last Glacial Maximum. (For interpretation of the references to color in this figure legend, the reader is referred to the web version of this article.)

Modified after McCulloch et al. (2010).

western basin as a combined effect of indirect human impact on a fragile environment already stressed by desiccation. So far, no coral ages of less than 7000 years have been observed in the Alboran Sea (Fig. 6).

\subsubsection{Mud volcano related seepage activity}

Hovland and Thomsen (1997) proposed a relation between the development of cold-water coral ecosystems and seepage of light hydrocarbons as trigger of local primary production. In this context, the mud volcanism in the Alboran Sea has the potential to support coldwater coral ecosystems as many mud volcanoes in the region are still active, e.g., the Carmen mud volcano, where gas bubbling was documented during the TTR-17 Leg 1 (Ivanov et al., 2009). However, Becker et al. (2009) showed that the presence of cold-water corals is not primarily due to nutrients linked to seepage activity but rather to the formation of seep-related carbonate crusts on elevated topography characterized by intense bottom currents and mixing resulting in increased food supply (Roberts et al., 2006). The Dhaka and Maya mud volcanoes are presently not active, and are therefore difficult to test for a possible relationship between seepage, nutrient supply and cold-water corals. However, oxygen and carbon isotopic values of Discanomalina coronata tests from the Dhaka MV (Table 3) do not show the strong isotopic anomalies reported for foraminifera associated with methane seeps (e.g., Sen Gupta et al., 1997; Rathburn et al., 2000; Hill et al., 2003). Therefore, the isotopic data do not lend support to important hydrocarbon seepage on the Dhaka mud volcano.

\section{Conclusion}

Cold-water coral-rich layers were found on the top of the Dhaka and Maya MVs in the Alboran Sea. On both mud volcanoes the extruded mud breccia provides the nucleation point for the colonization and development of the corals. The co-occurrence of cold-water corals and the benthic foraminifera $D$. coronata together with the associated in- and epi-fauna as observed in the Porcupine Basin and on the Rockall Bank (Margreth et al., 2009; Fig. 5) suggest that these ecosystems are in situ. Two phases of cold-water coral growth are observed: at Dhaka MV corals occur between around 4200 and 2200 years BP and at Maya MV between around 15,600 and 7600 years BP. The development of these ecosystems at different times on two mud volcanoes that are geographically close may probably relate to the nature of the substratum, which plays an important role for the cold-water coral colonization.

Data further suggest that only a small reef and/or isolated corals proliferated on the top of the Maya MV, whereas a more extended reef colonized the top of the Dhaka MV. At both mud volcanoes the coldwater coral development is related to times characterized by high nutrient availability as indicated by high abundance of planktonic $N$. incompta, which could have been triggered by upwelling and/or strong currents mobilizing horizontal nutrient fluxes. The shift from the $N$. incompta to the G. inflata dominated period, which reflects changing hydrographic conditions with a deep pycno-nutricline, occurs at the transition from wet to arid climatic conditions at the end of the African Humid Period at Maya MV. At Dhaka it is coeval with the initiation of complex human societies along the Mediterranean coasts with consequent impact on the natural vegetation culminating at about 3400 to 2400 years BP.

Supplementary materials related to this article can be found online at doi:10.1016/j.margeo.2011.02.006.

\section{Acknowledgements}

This study is funded by the Swiss National Science Foundation Projects 200021-111694 and 200020-117928, with additional support from the Commission for Oceanography and Limnology of the Swiss Academy of Sciences. Cruise TTR 17-Leg 1 (SAGAS-08 Cruise) was funded by the Spanish Projects CTM 2005-08071-C03-01 and CGL200613327-C04-04 (R\&D National Plan of the Ministry of Science and Innovation, Spain) and by UNESCO. LMP participation was supported by SAGAS project and the ESF EuroCORE-EuroMARGINS project MVSEIS (O1-LEC-EMA24F/PDCTM72003/DIV/40018). AR was financially supported by the Deutsche Forschungsgemeinschaft projects TRISTAN and Paläo-TRISTAN (Du 129/37-2 and Du 129/37-3), which he gratefully acknowledged.

The authors are deeply indebted to the Training Through Research Program (TTR). Thanks to the captain and crew of the R/V Professor Logacev (Moscow), thanks to Prof M. Ivanov (Moscow) and his students for support and collaboration during the cruise. C.F. Lopez Rodriguez is thanked for sampling core TTR17-MS419G at the core repository of University of Granada. L. Haxhiaj (IFM-GEOMAR) is thanked for his support with stable isotope measurements. P. Grootes and M. Hüls from the Leibniz-Laboratory for Radiometric Dating and Stable Isotope 
Research at Kiel University are greatly acknowledged for performing AMS ${ }^{14} \mathrm{C}$ dating. We thank three anonymous reviewers for their constructive feedback on the manuscript.

\section{References}

Akhmetzhanov, A.M., Ivanov, M.K., Kenyon, N.H., Mazzini, A., 2007. Deep-water cold seeps, sedimentary environments and ecosystems of the Black and Tyrrhenian Seas and Gulf of Cadiz. Preliminary Results of Investigations During the TTR-15 Cruise of Professor Logachev, June-August 2005: IOC Technical Series, 72. UNESCO, 99 pp.

Alvarez-Péréz, G., Busquets, P., De Mol, B., Sandoval, N.G., Canals, M., Casamor, J.L., 2005. Deep-water coral occurrences in the Straits of Gibraltar. In: Freiwald, A., Murray, J. M. (Eds.), Cold-Water Corals and Ecosystems. Springer-Verlag Berlin, pp. 207-221.

Baraza, J., Ercilla, G., 1996. Gas-charged sediments and large pockmark like features on the Gulf of Cadiz slope (SW Spain). Mar. Pet. Geol. 13, 253-261.

Baraza, J., Ercilla, G., Nelson, C.H., 1999. Potential geologic hazards on the eastern Gulf of Cadiz slope (SW Spain). Mar. Geol. 155 (1-2), 191-215.

Barriendos, M., Martin-Vide, J., 1998. Secular climatic oscillations as indicated by catastrophic floods in the Spanish Mediterranean coastal area (14th-19th centuries). Clim. Change 38, 473-491.

Baruch, U., 1994. The Late Quaternary pollen record of the Near East. In: Bar-Yosef, O., Kra, R.S. (Eds.), Late Quaternary Chronology and Paleoclimate of the Eastern Mediterranean: Radiocarbon, pp. 103-119.

Basso, D., Spezzaferri, S., 2000. The distribution of living (stained) benthic foraminifera in Iskenderun Bay: a statistical approach. Boll. Soc. Paleont. Ital. 29, 356-370.

Becker, E.L., Cordes, E.E., Macko, S.A., Fisher, C.R., 2009. Importance of seep primary production to Lophelia pertusa and associated fauna in the Gulf of Mexico. Deep Sea Res. I 56, 786-800.

Beuck, L., Freiwald, A., Taviani, M., 2010. Spatiotemporal bioerosion patterns in deepwater scleractinians from off Santa Maria di Leuca (Apulia, Ionian Sea). Deep Sea Res. II 57, 458-470.

Bucca, P.J., Kinder, T.H., 1984. An example of meteorological effects on the Alboran Sea Gyre. J. Geophys. Res. 89, 751-757.

Cacho, I., Grimalt, J.O., Canals, M., Sbaffi, L., Shackleton, N.., Schönfeld, J., Zahn, R., 2001 Variability of the western Mediterranean sea surface temperature during the last 25,000 years and its connection with the Northern Hemisphere climatic changes. Paleoceanography 16, 40-52.

Chalouan, A., Saji, R., Michard, A., Bally, A.W., 1997. Neogene tectonic evolution of the Southwestern Alboran Basin as inferred from seismic data off Morocco. A. A. P. G. Bull. 81, 1161-1184.

Clarke, K.R., 1993. Non-parametric multivariate analyses of changes in community structure. Aust. J. Ecol. 18, 117-143.

Clarke, K.R., Gorley, R.N., 2006. PRIMER v6: User Manual/Tutorial, PRIMER-E, Plymouth

Clarke, K.R., Warwick, R.M., 2001. A further biodiversity index applicable to species lists: variation in taxonomic distinctness. Mar. Ecol. Prog. Ser. 216, 265-278.

Clifford, D.H.T., Stephenson, W., 1975. An Introduction to Numerical Classification. Academic Press, New York.

Comas, M.C., Ivanov, M., 2006. Eastern Alboran margin: the transition between the Alboran and the Balearic-Algerian Basin. Introduction. In: Kenyon, N.H., Ivanov, M.K., Akhmetzhanov, A.M., Kozlova, E.V. (Eds.), Interdisciplinary Geoscience Studies of the Gulf of Cadiz and Western Mediterranean Basin: IOC Tech. Ser., 70, pp. 48-49. UNESCO.

Comas, M.C., Pinheiro, L.M., 2007. Mud volcanism, gas hydrates and hydrocarbon-rich fluid escape structures in the Gibraltar Arc System. Exploring Escarpment Mud Mound Systems and Mud Volcanoes with New European Strategies for Sustainable Mid-Depth Coring, Magellan Workshop. Murten, Switzerland.

Comas, M.C., Garcia-Dueñas, V., Jurado, M.J., 1992. Neogene tectonic evolution of the Alboran Sea. In: Maldonado, A. (Ed.), The Alboran Sea. Geo-Mar. Lett. Spec. Issue, 12, pp. $157-164$

Comas, M.C., Platt, J., Soto, J.I., Watts, T., 1999. The origin and tectonic history of the Alboran Basin: insights from Leg 161 results. In: Zahn, R., Comas, M.C., Klaus, A. (Eds.), ODP Proc., Sci. Results, 161. Texas A \& M University, College Station, pp. 555-580.

Comas, M.C., Soto, J.I., BASALCALB cruise (TTR-9 Leg 3) Scientific Party, 2000. A tectonic overview on the mud diapirs and related mud volcanoes in the Alboran Basin. Geological Processes on European Continental Margins (TTR-9 Post-Cruise Conference), Granada, Spain: IOC Workshop Report, 168, pp. 29-30.

Comas, M.C., Soto, J.I., Taludker, A.R., TTR-12 Leg 3 (MARSIBAL-1) Scientific Party, 2003a. Discovering active mud volcanoes in the Alboran Sea (Western Mediterranean). IOC Workshop Report, 187, pp. 14-16. UNESCO.

Comas, M.C., Talukder, A.R., Soto, J.I., 2003b. Mud volcanoes in the Alboran Sea: learning from occurrences in the western Mediterranean. Geophys. Res. Abstr. 5, 12617.

Cruzado, A., 1985. Chemistry of Mediterranean waters. In: Margalef, R. (Ed.), Western Mediterranean. Pergamon, Oxford, U.K, pp. 126-147.

Cuffey, K.M., Clow, G.D., 1997. Temperature, accumulation and ice sheet elevation in central Greenland through the last deglaciation transition. J. Geophys. Res. 102, 26383-26396.

Dafner, E.V., Sempere, R., Bryden, H.L., 2001. Total organic carbon distribution and budget through the Strait of Gibraltar in April 1998. Mar. Chem. 73, 233-252.

De Menocal, P.D., Ortiz, J., Guilderson, T., Sarnthein, M., 2000. Coherent high- and low-latitude climate variability during the Holocene warm period. Science 288 2198-2202.

De Mol, B., Van Rensbergen, P., Pillen, S., Van Herreweghe, K., Van Rooij, D., McDonnell A., Huvenne, V., Ivanov, M., Swennen, R., Henriet, J.P., 2002. Large deep-water coral banks in the Porcupine Basin, southwest of Ireland. Mar. Geol. 188, 193-231.
Dewey, J.F., Helma, M.L., Turco, E., Hutton, D.W.H., Knott, S.D., 1989. Kinematics of the western Mediterranean. In: Coward, M.P., Dietrich, D., Park, R.G. (Eds.), Alpine Tectonics: Geol. Soc. Lond. Spec. Publ. , pp. 265-283.

Dorschel, B., Hebbeln, D., Rüggeberg, A., Dullo, C., Freiwald, A., 2005. Growth and erosion of a cold-water coral covered carbonate mound in the Northeast Atlantic during the Late Pleistocene and Holocene. Earth Planet. Sci. Lett. 233, 33-44.

Dullo, W.C., Flögel, S., Rüggeberg, A., 2008. Cold-water coral growth in relation to the hydrography of the Celtic and Nordic European continental margin. Mar. Ecol. Prog. Ser. 371, 165-176.

Fairbanks, R.G., Wiebe, P.H., 1980. Foraminifera and chlorophyll maximum: vertical distribution, seasonal succession, and paleoceanographic significance. Science 209, 1524-1526.

Fairbanks, R.G., Sverdlove, M., Free, R., Wiebe, P.H., Bé, A.W.H., 1982. Vertical distribution of living planktonic foraminifera from the Panama Basin. Nature 298, 841-844.

Ferdelman, T.G., Kano, A., Williams, T., Henriet, J.-P., the Expedition 307 Scientists (Eds.), 2006. Proceedings of the Integrated Ocean Drilling Program, 307. Integrated Ocean Drilling Program Management International, Inc, Washington, DCdoi10.2204/iodp. proc.307.104.2006.

Fernández-Ibáñez, F., Soto, J.I., Zoback, M.D., Morales, J., 2007. Present-day stress field in the Gibraltar Arc (western Mediterranean). J. Geophys. Res. 112, B08404doi10.1029/2006JB004683.

Fernandez-Puga, M.C., Vasquez, J.T., Somoza, L., Diaz del Rio, V., Medialdea, T., Mata, M.P. Léon, R., 2007. Gas-related morphologies and diapirism in the Gulf of Cadiz. Geo-Mar. Lett. 27 (2-4), 213-221.

Field, J.G., Clarke, K.R., Warwick, R.M., 1982. A practical strategy for analysing multispecies distribution patterns. Mar. Ecol. Prog. Ser. 8, 37-52.

Foubert, A., Depreiter, D., Beck, T., Maignien, L., Pannemans, B., Frank, N., Blamart, D., Henriet, J.-P., 2008. Carbonate mounds in a mud volcano province off north-west Morocco: key to processes and controls. Mar. Geol. 248, 74-96.

Frederiksen, R., Jensen, A., Westerberg, H., 1992. The distribution of scleractinian coral Lophelia pertusa around the Faroe Islands and the relation to intertidal mixing. Sarsia 77, 157-171.

Freiwald, A., 2002. Reef-forming cold-water corals. In: Wefer, G., Billett, D., Hebbeln, D., Jørgensen, B.B., Schlüter, M., van Weering, T. (Eds.), Ocean Margin Systems. Springer Verlag, Berlin, Heidelberg, pp. 365-385.

Freiwald, A., Fosså, J.H., Grehan, A., Koslow, T., Roberts, J.M., 2004. Cold-water coral reefs. Biodiversity Series, 22. UNEP-WCMC, Cambridge, UK. 84 pp.

Freiwald, A., Beuck, L., Rüggeberg, A., Taviani, M., Hebbeln, D., 2009. The white coral community in the central Mediterranean Sea revealed by ROV surveys. Oceanography $22,58-74$.

Frisia, S., Borsato, A., Mangini, A., Spötl, C., Madonia, G., Sauro, U., 2006. Holocene climate variability from a discontinuous stalagmite record and the Mesolithic to Neolithic Transition. Quat. Res. 66, 388-400.

Frizon de Lamotte, D., Michard, A., Saddiqi, O., 2006. Quelques développements récents sur la géodinamique du Maghreb. C. R. Géosci. 338 (1-2), 1-10.

García Lafuente, J., Delgado, J., Vargas, M., Vargas, M., Plaza, F., Sarhan, T., 2002. Low frequency variability of the exchanged flows through the Strait of Gibraltar during CANIGO. Deep Sea Res. II 49, 4051-4067.

Gardner, J.M., 2001. Mud volcanoes revealed and sampled on the western Maroccan continental margin. Geophys. Res. Lett. 28, 334-342.

Gutscher, M.A., Malod, J., Rehault, J.P., Contrucci, I., Klingelhoefer, F., Mendes-Victor, L., Spakman, W., 2002. Evidence for active subduction beneath Gibraltar. Geology 30, 1071-1074.

Henriet, J.P., De Mol, B., Pillen, S., Vanneste, M., Van Rooij, D., Versteeg, W., Croker, P.F., Shannon, P.M., Unnithan, V., Bouriak, S., Chachkine, P., 1998. Gas hydrate crystals may help build reefs. Nature 391, 648-649.

Hill, T.M., Kennett, J.P., Spero, H.J., 2003. Foraminifera as indicators of methane-rich environments, a study of modern methane seeps in Santa Barbara Channel, California. Mar. Micropaleontol. 49, 123-138.

Hovland, M., Thomsen, E., 1997. Cold-water corals-are they hydrocarbon seep related? Mar. Geol. 137, 159-164.

Huvenne, V.A.I., Blondel, P., Henriet, J.P., 2002. Textural analyses of sidescan sonar imagery from two mound provinces in the Porcupine Seabight. Mar. Geol. 189 (3-4), 323-341.

Ivanov, M.K., Kenyon, N., Nielsen, T., Wheeler, A., Monteiro, J., Gardner, J., Comas, M., Akhmanov, G., Akhmetzhanov, A., Scientific Party of the TTR-9 cruise, 2000. Goals and principal results of the TTR-9 cruise. Proc. Int. Conf. Geological Processes on European Continental Margins: IOC/UNESCO Workshop Report, 168, pp. 3-4.

Ivanov, M.K., Pinheiro, L., Stadnitskaia, A., Blinova, V., 2001. Hydrocarbon seeps on Deep Portuguese Margin. Final Proc. 11th Meeting of the E. G. U., Strasbourg, France, CC11, 160.

Ivanov, M.K., Kenyon, N., Comas, M., Pinheiro, L.M., Laberg, J.-S., Shipboard Scientific Party, 2009. Introduction to the TTR-17 results. Geo-Marine Research on the Mediterranean and European-Atlantic Margins. International Conference and TTR-17 Post-Cruise Meeting of the Training-through-Research Programme. Granada, Spain, 2-5 February 2009. IOC Workshop Report No. 220 (English), UNESCO. 52 pp.

Jimenez-Espejo, F.J., Martinez-Ruiz, F., Sakamoto, T., Iijima, K., Gallego-Torres, D., Harada, N., 2008. Paleoenvironmental changes in the Western Mediterranean since the last glacial maximum: high resolution multiproxy record from the AlgeroBalearic basin. Palaeogeogr. Palaeoclimatol. Palaeoecol. 246, 292-306.

Kenyon, N., Ivanov, M., Akhmetzanov, A., Akhmanov, G., 2001. Interdisciplinary geoscience research on the north east Atlantic margin. IOC UNESCO Tech. Ser., 76.

Kopf, A., Bannert, B., Brückmann, W., Dorschel, B., Foubert, A.T.G., Grevemeyer, I., Gutscher, M. A., Hebbeln, D., Heesemann, B., Hensen, C., Kaul, N.E., Lutz, M., Magalhaes, V.H., Marquardt, M.J., Marti, A.V., Nass, K.S., Neubert, N., Niemann, H., Nuzzo, M., Poort, J.P.D., Rosiak, U.D., Sahling, H., Schneider, J., Somoza, L., Thiebot, E., Wilkop, T.P., 2004. Report 
and preliminary results of Sonne cruise SO175, Miami-Bremerhaven, 12.11-30.12.2003. Berichte Fachbereich Geowissenschaften Universität Bremen 228.

Kruskal, J.B., 1964. Multidimensional scaling by optimizing goodness of fit to a nonmetric hypothesis. Psychometrika 29, 1-27.

Kruskal, J.B., Wish, M., 1978. Multidimensional Scaling. Sage Publication, Beverly Hills, California.

Lambeck, K., Smither, C., Johnston, P., 1998. Sea-level change, glacial rebound and mantle viscosity for northern Europe. Geophys. J. Int. 134 (1), 102-144.

León, R., Somoza, L., Medialdea, T., González, F.J., Díaz-del-Río, V., Fernández-Puga, M.C., Maestro, A., Mata, M.P., 2007. Sea-floor features related to hydrocarbon seeps in deepwater carbonate-mud mounds of the Gulf of Cádiz: from mud flows to carbonate precipitates. Geo-Mar. Lett. 27, 237-247.

Liu, Z Wang Y, Gallimore, R, Gasse, F, Johnson, T, de Menocal, P, Adkins, J Notaro, M, Prentice, I.C., Kutzbach, J., Jacob, R., Behling, P., Wang, L., Ong, E., 2007. Simulating the transient evolution and abrupt change of Northern Africa atmosphere-oceanterrestrial ecosystem in the Holocene. Quat. Sci. Rev. 26, 1818-1837.

Loeblich Jr., A.R., Tappan, H., 1988. Foraminiferal Genera and Their Classification, 2 vols. Van Nostrand Reinhold Company, New York. 1182 pp.

Mackensen, A., Sejrup, H., Jansen, E., 1985. The distribution of living benthic foraminifera on the continental slope and rise off Southwest Norway. Mar. Micropaleontol. 9, 275-306.

Margreth, S., Rüggeberg, A., Spezzaferri, S., 2009. Benthic foraminifera as proxies for coldwater coral reef ecosystems along the Irish Margin. Deep Sea Res. I 56, 2216-2234.

Masson, D.G., Bett, B.J., Billett, D.S.M., Jacobs, C.L., Wheeler, A.J., Wynn, R.B., 2003. The origin of deep-water, coral-topped mounds in the northern Rockall Trough, Northeast Atlantic. Mar. Geol. 194, 159-180.

Mastrototaro, F., D'Onghia, G., Corriero, G., Matarrese, A., Maiorano, P., Panetta, P., Gherardi, M., Longo, C., Rosso, A., Sciuto, F., Sanfilippo, R., Gravili, C., Boero, F., Taviani, M., Tursi, A., 2010. Biodiversity of the white coral bank off Cape Santa Maria di Leuca (Mediterranean Sea): An update. Deep Sea Res. II 57, 412-430.

Mazurenko, L.L., Soloviev, V.A., Belenkaya, I., Ivanov, M.K., Pinheiro, L.M., 2002. Mud volcano gas hydrates in the Gulf of Cadiz. Terra Nova 14, 321-329.

McCulloch, M., Taviani, M., Montagna, P., López Correa, M., Remia, A., Mortimer, G., 2010. Proliferation and demise of deep-sea corals in the Mediterranean during the Younger Dryas. Earth Planet. Sci. Lett. 298, 143-152.

Millot, C., 2009. Another description of the Mediterranean Sea outflow. Prog. Oceanogr. doi10.1016/j.pocean.2009.04.016.

Morel, A., 1991. Light and marine photosynthesis: a spectral model with geochemical and climatological implications. Prog. Oceanogr. 26, 263-306.

Pérez-Belzuz, F., Alonso, B., Ercilla, G., 1997. History of mud diapirism and trigger mechanism in the Western Alboran Sea. Tectonophysics 282, 399-422.

Pérez-Folgado, M., Sierro, F.J., Flores, J.A., Cacho, I., Grimalt, J.O., Zahn, R., Shackleton, N.J. 2003. Western Mediterranean planktonic foraminifera events and millennial climatic variability during the last 70 kyr. Mar. Micropaleontol. 48 (1-2), 49-70.

Pinheiro, L.M., Ivanov, M.K., Sautkin, A., Akhmanov, G., Magalhães, V.H., Volkonskaya, A., Monteiro, J.H., Somoza, L., Gardner, J., Hamouni, N., Cunha, M.R., 2003. Mud volcanism in the Gulf of Cadiz: results from the TTR-10 cruise. Mar. Geol. 195, 131-151.

Pujol, C., Vergnaud-Grazzini, C., 1989. Palaeoceanography of the Last Deglaciation in the Alboran Sea (Western Mediterranean): stable isotopes and planktonic foraminiferal records. Mar. Micropaleontol. 15, 153-179.

Rathburn, A.E, Levin, LA, Held, ZA, Lohmann, K.C, 2000. Benthic foraminifera associated with cold methane seeps on the Northern Californian Margin: ecology and stable isotopic composition. Mar. Micropaleontol. 38, 247-266.

Reynolds, L.A., Thunell, R.C., 1986. Seasonal production and morphologic variation of Neogloboquadrina pachyderma (Ehrenberg) in the Northeast Pacific. Micropaleontology $32,1-18$.

Riehl, S., 2009. Archeaeobotanical evidence for the interrelationship of agricultural decision-making and climate changes in the ancient Near East. Quat. Int. 197, 93-114.

Roberts, N., 1989. The Holocene: An Environmental History. Blackwell, Oxford. 227 pp.

Roberts, J.M., Wheeler, A.J., Freiwald, A., 2006. Reefs of the deep: the biology and geology of cold-water coral ecosystems. Science 312, 543-547.

Rodriguez, S., Querol, X., Alastuey, A., Kallos, G., Kakaliagou, O., 2001. Saharan dust contributions to PM10 and TSP levels in Southern and Eastern Spain. Atmos. Environ. 35, 2433-2447.

Rogers, A.D., 1999. The biology of Lophelia pertusa (Linnaeus 1758) and other deepwater reef forming corals and impact from human activities. Int. Rev. Hydrobiol. 84, 315-406.

Rogerson, M., Cacho, I., Jimenez-Espejo, F.J., Reguera, M.I., Sierro, F.J., Martinez-Ruiz, F. Frigola, J., Canals, M., 2008. A dynamic explanation for the origin of the Western Mediterranean organic rich layers. Geochem. Geophys. Geosyst. 9, Q07U01doi10.1029/2007GC001936.

Rohling, E.J., De Rijk, S., 1999. The Holocene climate optimum and last glacial maximum in the Mediterranean: the marine oxygen isotopes record. Mar. Geol. 153, 57-75.
Rohling, E.J., Den Dulk, M., Pujol, C., Vergnaud-Grazzini, C., 1995. Abrupt hydrological change in the Alboran sea (western Mediterranean) around 8000 yrs BP. Deep Sea Res. I 42 (9), 1609-1619.

Rosso, A., Vertino, A., Di Geronimo, I., Sanfilippo, R., Sciuto, F., Di Geronimo, R., Violanti, D., Corselli, C., Taviani, M., Mastrototaro, F., Tursi, A., 2010. Hard- and soft-bottom thanatofacies from the Santa Maria di Leuca deep-water coral province, Mediterranean. Deep Sea Res. II 57, 360-379.

Rüggeberg, A., Dorschel, B., Dullo, W.C., Hebbeln, D., 2005. Sedimentary patterns in the vicinity of a carbonate mound in the Hovland Mound Province, northern Porcupine Seabight. In: Freiwald, A., Murray, J.M. (Eds.), Cold-Water Corals and Ecosystems. Springer-Verlag, Berlin, pp. 87-112.

Rüggeberg, A., Dullo, W.C., Dorschel, B., Hebbeln, D., 2007. Environmental changes and growth history of Propeller Mound, Porcupine Seabight: evidence from benthic foraminiferal assemblages. Int. J. Earth Sci. 96, 57-72.

Sautkin, A., Talukder, A.R., Comas, M.C., Soto, J.I., Alekseev, A., 2003. Mud volcanoes in the Alboran Sea: evidence from micropaleontological and geophysical data. Mar. Geol. 195, 237-261.

Sautter, L.R., Thunell, R.C., 1989. Seasonal succession of planktonic foraminifera: results from a four-year series sediment traps experiment in the Northeast Pacific. J. Foramineferal Res. 19 (4), 253-267.

Schönfeld, J., 2002. Recent benthic foraminiferal assemblages in deep high-energy environments from the Gulf of Cadiz (Spain). Mar. Micropaleontol. 44, 141-162.

Schröder-Ritzrau, A Freiwald, A Mangini, A 2005. U/Th-dating of deep-water corals from the eastern North Atlantic and the western Mediterranean Sea. In: Freiwald, A., Murray, J.M. (Eds.), Cold-Water Corals and Ecosystems. Springer-Verlag Berlin, pp. 157-172.

Sen Gupta, B.K., Platon, E., Bernhard, J.M., Aharon, P., 1997. Foraminiferal colonization of hydrocarbon-seep bacterial mats and underlying sediment, Gulf of Mexico slope. J. Foramineferal Res. 27, 292-300.

Siani, G., Paterne, M., Arnold, M., Bard, E., Métivier, B., Tisnerat, N., Bassinot, F., 2000. Radiocarbon reservoir ages in the Mediterranean Sea and Black Sea. Radiocarbon 42 (2), 271-280.

Siani, G., Paterne, M., Michel, E., Sulpizio, R., Sbrana, A., Arnold, M., Haddad, G., 2001. Mediterranean Sea surface radiocarbon reservoir age changes since the last glacial maximum. Science 294, 1917-1920.

Somoza, L. Ivanov, M.K., Pinheiro, L.M., Maestro, A., Lowrie, A., Vasquez, J.T., Gardner, J., Leon, R., Fernandez-Puga, M.C., 2000. Structural and tectonic control of fluid seeps and mud volcanoes in the Gulf of Cadiz. Proceedings of the TTR-10 Post-Cruise Meeting, Mozenka, Moscow.

Somoza, L., Díaz-del-Rio, V., Leon, R., Ivanov, M., Fernandez-Puga, M.C., Gardner, J.M., Hernandez-Molina, F.J., Pinheiro, L.M., Rodero, J., Lobato, A., 2003. Seabed morphology and hydrocarbon seepage in the Gulf of Cádiz mud volcano area: acoustic imagery, multibeam and ultra-high-resolution seismic data. Mar. Geol. 195, 153-176.

Spezzaferri, S., Coric, S., 2001. Ecology of Karpatian (early Miocene) foraminifers and calcareous nannoplankton from Laa an der Thaya, Lower Austria: a statistical approach. Geol. Carpath. 52 (6), 361-374

Stuiver, M., Reimer, P.J., 1993. Extended C-14 Data-Base and Revised Calib 3.0 C-14 Age Calibration Program. Radiocarbon 35 (1), 215-230.

Swezey, C., 2001. Eolian sediment responses to late Quaternary climate changes: temporal and spatial patterns in the Sahara. Palaeogeogr. Palaeoclimatol. Palaeoecol. 167, 119-155.

Talukder, A.R., Comas, M.C., Soto, J.I., 2003. Pliocene to Recent mud diapirism and related mud volcanoes in the Alboran Sea (Western Mediterranean). In: Van Rensbergen, P., Hillis, R.R., Maltman, A.J., Morley, C.K. (Eds.), Subsurface Sediment Mobilization: Geological Society, London, Spec. Publ., 216, pp. 443-459.

Taviani, M., Remia, A., Corselli, C., Freiwald, A., Malinverno, E., Mastrototaro, F., Savini, S., Tursi, A., 2005. First geo-marine survey of living cold-water Lophelia reefs in the Ionian Sea (Mediterranean basin). Facies 50, 409-417.

Van Rensbergen, P., Depreiter, D., Pannemans, B., Moerkerke, G., Van Rooij, D., Marsset, B., Akhmanov, G., Blinova, V., Ivanov, M., Rachidi, M., Magalhaes, V., Pinheiro, L., Cunha, M., Henriet, J.P., 2005. The El Arraiche mud volcano field at the Moroccan Atlantic slope, Gulf of Cadiz. Mar. Geol. 219 (1), 1-17.

Van Zeist, W., Woldring, H., Stapert, D., 1975. Late Quaternary vegetation and climate of southwestern Turkey. Palaeohistoria 17, 55-142.

Weaver, P.P.E., Pujol, C., 1988. History of the last deglaciation in the Alboran Sea (Western Mediterranean) and adjacent North Atlantic as revealed by coccolith floras. Palaeogeogr. Palaeoclimatol. Palaeoecol. 64, 35-42.

Wienberg, C., Hebbeln, D., Fink, H., Mienis, F., Dorschel, B., Vertino, A., Lopez Correa, M., Freiwald, A., 2009. Scleractinian cold-water corals in the Gulf of Cadiz. First clues about their spatial and temporal distribution. Deep Sea Res. I 56, 1873-1893.

Zanchetta, G., Drysdale, R.N., Hellstrom, J.C., Fallick, A.E., Isola, I., Gagan, M.K., Pareschi, M.T., 2007. Enhanced rainfall in the Western Mediterranean during deposition of sapropel S1: stalagmite evidence from Corchia cave (Central Italy). Quat. Sci. Rev. 26, 279-286. 